\title{
Effect of Biogas Digestate and Mineral Fertilisation on the Soil Properties and Yield and Nutritional Value of Switchgrass Forage
}

\author{
Aleksandra Głowacka ${ }^{1, *(\mathbb{D}, \text { Bogdan Szostak }}{ }^{2, *}$ and Renata Klebaniuk ${ }^{2}$ \\ 1 Department of Plant Cultivation Technology and Commodity, University of Life Sciences in Lublin, \\ 15 Akademicka Street, 20-950 Lublin, Poland \\ 2 Institute of Animal Nutrition and Bromatology, University of Life Sciences in Lublin, 13 Akademicka Street, \\ 20-950 Lublin, Poland; renata.klebaniuk@up.lublin.pl \\ * Correspondence: aleksandra.glowacka@up.lublin.pl (A.G.); bogdan.szostak@up.lublin.pl (B.S.); \\ Tel.: +48-81-445-66-23
}

Received: 5 February 2020; Accepted: 25 March 2020; Published: 1 April 2020

\begin{abstract}
The aim of this study was to assess the effect of a three-year application of digestate from an agricultural biogas plant on the physicochemical properties of highly acidic $\mathrm{pH}_{\mathrm{KCl}} 4.4 \pm 0.23$, silty loam soils with low macronutrient content and on the yield and nutritional value of switchgrass (Panicum virgatum L.) biomass harvested for green fodder. The experiment included the following treatments: (1) O (control)—no fertilisation, (2) NPK-mineral fertilisation with (in $\mathrm{kg} \mathrm{ha}^{-1}$ ) $150 \mathrm{~N}$, $53.0 \mathrm{P}$ and $105 \mathrm{~K}$, (3) biogas digestate at $30 \mathrm{~m}^{3} \mathrm{ha}^{-1}$ and (4) biogas digestate at $60 \mathrm{~m}^{3} \mathrm{ha}^{-1}$. The higher application rate of biogas digestate significantly reduced soil acidity to $\mathrm{pH}_{\mathrm{KCl}} 4.9 \pm 0.18$ and improved its sorption properties. It also increased the soil organic matter content from $5.6 \pm 0.21$ to $6.4 \pm 0.22 \mathrm{~g} \mathrm{C}_{\text {org }} \mathrm{kg}^{-1}$ and of $\mathrm{K}$ and $\mathrm{Zn}$. The higher level of biogas digestate significantly increased switchgrass yield to $5.15 \pm 0.26 \mathrm{tha}^{-1}$. The lower application rate of biogas digestate resulted in forage yield of $4.30 \pm 0.20 \mathrm{tha}^{-1}$ comparable to that obtained after mineral fertilisation $\left(4.33 \pm 0.22 \mathrm{t} \mathrm{ha}^{-1}\right)$. Following application of mineral fertilisers and the higher level of biogas digestate, the number of panicles per plant $(150 \pm 2.49-157 \pm 0.6 .17)$, panicle height $(107 \pm 1.98-114 \pm 2.08)$, crude ash content $(61.2 \pm 0.43-65.5 \pm 0.38)$ and protein content $(106 \pm 0.59-92 \pm 1.11)$ in the switchgrass biomass from the first cut were higher than in the case of unfertilised soil $(110 \pm 3.81,93 \pm 1.32,55.5 \pm 0.40$, $80.3 \pm 0.37)$. The use of mineral fertilisers and biogas digestate increased the content of protein, $P$ and $\mathrm{Mg}$ in biomass from the second cut. The results suggest that the use of digestate improved the physicochemical properties of highly acidic soil and increased the yield of switchgrass forage without diminishing its nutritional value.
\end{abstract}

Keywords: switchgrass; digestate; yield; soil properties; nutritional value; mineral composition

\section{Introduction}

Climate change and increasingly frequent extreme weather events have a significant impact on crop growth and yield. An increase in temperature, a reduction in the amount of precipitation or its high irregularity and the resulting rapid rainfall and prolonged droughts, result in reduced yields of plants grown for both consumption and fodder purposes. These negative phenomena are also expected to intensify in Europe [1]. This makes it necessary to introduce new crop species, less sensitive to adverse environmental conditions, which can be a good source of feed for farm animals. One of these species is switchgrass. Switchgrass (Panicum virgatum L.) is a perennial plant of the C4 photosynthetic type, native to North America [2,3]. For more than 70 years it has been widely used in the US on the Great Plains and in the Midwest on pastures [4-6]. Cultivation of switchgrass is not widespread in Poland. 
However, according to Piłat et al. [7], switchgrass can be an alternative source of animal feed, especially in areas with severe water shortages during the summer. Switchgrass is also used in phytoremediation, soil protection against degradation, as an ornamental plant and a habitat for wild birds [3,8]. It is also considered to be one of the most important perennial energy crops. Switchgrass biomass can be used for direct combustion, and for the production of bioethanol or biogas [9-13]. Switchgrass is characterised by high biomass production potential, easy adaptation to unfavourable conditions, tolerance to water shortages and low nutrient content of soil $[14,15]$. Due to its well-developed root system reaching up to two metres deep, it is tolerant of drought conditions [16-20]. Although switchgrass is a plant with relatively low environmental requirements, studies show that it responds favourably to applied mineral, mainly nitrogen $(\mathrm{N})$, fertilisation. Recommended $\mathrm{N}$ fertilisation rates vary depending on the soil conditions, the variety and the use of the plantation [16,21-23]. Fertilisation can affect not only the size but also the quality of the biomass obtained and its nutritional value $[9,24]$, such as protein content [25,26], Ca, Mg and P concentrations [26].

The various types of gas biofuels include biogas. It is formed in the process of the biological decomposition of organic matter by methanotroph bacteria under anaerobic conditions. Biogas is principally produced in agricultural biogas plants, where the substrates are animal wastes, the biomass of plants specially cultivated for this purpose, and waste from the agricultural and food industry $[27,28]$. During the fermentation process, only a portion of the co-substrates undergoes transformation into biogas. The transformations the charge undergoes during fermentation are the removal of easily-transformable carbon compounds, leaving behind compounds more difficult to decompose, the transformation of nitrogen compounds into ammonia nitrogen, the destruction of pathogenic bacteria and viruses and parasite eggs, an increase in amino acid and $\mathrm{B}_{12}$ vitamin content, no significant changes in the content of macro- and micronutrients and a change in the $\mathrm{C} / \mathrm{N}$ ratio. $\mathrm{A}$ by-product of biogas production is the digestate. Digestate composition depends on the fermentation process and on the substrates used and may have varied fertilising value [29]. Agricultural plant digestate is a relatively new type of waste, which can be used to fertilise soil as it contains a high amount of organic matter and other nutrients necessary for the healthy growth of plants and other soil organisms. Digestate is most commonly used to fertilise field crops and pastures. Biogas residue has high organic carbon and total $\mathrm{N}$ content and can have a beneficial effect on soil fertility [30-34]. It was observed that application of biogas digestate significantly increased soil $\mathrm{pH}$, content of organic carbon, total $\mathrm{N}$ and available forms of $\mathrm{P}, \mathrm{K}$, and $\mathrm{Mg}$ [31,35]. According to Smith et al. [36], biogas digestate has great potential to increase soil $\mathrm{C}$ sequestration. This is the result of stabilisation of organic matter by anaerobic digestion through degradation of the most labile fraction [37]. However, this is not always the case [29]. Garg et al. [38] showed that the application of digestate from agricultural waste reduced bulk density and increased saturated hydraulic conductivity and moisture retention capacity of soils. We were unable to find studies on the impact of digestate on the sorption properties of soil. Furthermore, direct comparison of results between studies is often difficult due to variation in feedstocks, the anaerobic digestion process and digestate properties, as well as the rates and methods of digestate application. Moreover, many studies are based on a single growing season or on short pot experiments under controlled conditions [27,29].

The incorporation of organic waste into the soil may not only change its chemical composition and physical characteristics but may also affect living organisms. Ecotoxicological tests conducted by Różyło et al. [30] and Stefaniuk et al. [31] suggested that application of biogas digestate had a positive or insignificant effect on the test organisms ( $V$. fischer, Microbacterium ssp., Staphylococcus warneri or Pichia anomala) as compared to the control soil. Odlare et al. [39] found that soil microbial biomass and metabolic activity are stimulated by the application of digestate, which is attributed to increased $C$ and nutrient availability. According to Insam et al. [40], digestate is likely to enhance microbial activity and biomass, not only compared to mineral fertilisation but in most cases also compared to undigested manure. We found only one opinion stating that food-based digestate application decreases 
numbers of earthworms observed in the field [29]. This was most likely linked to the large amount of ammonium-N introduced with the digestate.

The effects of digestate fertilising on the composition and quality of wheat (Triticum aestivum L.) grain [41], soy (Glicyne max (L.) Merr) yields and bean (Phaseolus vulgaris L.) composition [42], yields of various grass, i.e., perennial ryegrass (Lolium perenne L.) and creeping red fescue (Festuca rubra subsp. rubra) [43], corn (Zea mays L.) [44] and other annual species cultivated to obtain biomass for energy production [28] have also been studied. In a study by Różyło et al. [41], winter wheat yield following digestate application was similar to that obtained with mineral fertilisation. In addition, biogas digestate increased the content of protein, wet gluten, and phenols in wheat grain compared to NPK fertilisation. Three-year application of waste did not result in exceedances of international standards for heavy metal content in grain. Abbubaker et al. [45] reported that biomass yields of spring wheat following application of digestate was higher than for the control soil but lower than after application of undigested pig slurry. Andruschkewitsch et al. [43] conducted five-month pot experiments with three different grass species (Lolium perenne, Trisetum flavescens and Festuca rubra subsp. Rubra) fertilised with digestate or mineral nitrogen fertiliser. Digestate application increased biomass of all grass species, but only the yield of L. perenne increased with the rate of digestate. Long-term application of digestate could lead to a shift in species composition in grasslands. Walsh et al. [46] reported that application of organic fertilisers derived from anaerobic digestion resulted in similar yields of grass to those obtained when an NPK (nitrogen, phosphorus, potassium) compound fertiliser was applied, and statistically greater yield than when straight $\mathrm{N}$ inorganic fertiliser was applied. The effect of digestate on the content of protein in forage and its digestibility was insignificant. However, digestate application decreased the percentage of clover in the harvested biomass. This may be important because of the dietary benefits to livestock of the presence of clover in grass swards and silage. Numerous studies confirm the beneficial effect of digestate on the yield of other grass species, i.e., for Dactylis glomerata [47], Phalaris arundinacea and (x Festulolium pabulare) $[48,49]$.

One disadvantage of using digestate as fertiliser is the risk of introducing pollutants, including heavy metals. In addition, inappropriate storage or application of anaerobic digestates can lead to gaseous nitrogen emissions and/or nutrient leaching and runoff into surface and ground waters [49]. Another problem associated with the use of digestate is the emission of odours [50]. The environmental risk potential following application of anaerobic digestates depends on factors such as fertilisation strategies, soil texture, topography, precipitation and cropping systems. Other important factors include the properties of the digestate and the application rates.

Literature indicates that in general, digestate is highly suitable for use in soil fertilising, it does not constitute a toxicological hazard, and its fertilising and crop generation effects depend on the dose applied and digestate properties, which differ greatly among individual biogas plants. However, the studies mentioned are mostly short-term projects, to a large degree, pot experiments conducted under controlled conditions. Few studies investigate the issue of digestate fertilising of perennial crops. We found no research on the effect of digestate on the forage yield and nutritional value of switchgrass.

The objective of the presented studies was to assess the effect of a three-year application of digestate from an agricultural biogas plant on the physicochemical properties of very acidic soils with low mineral content and on the yield and nutritional value of the biomass of switchgrass harvested for green fodder. An additional objective was to compare the effectiveness of the application of the digestate with traditional mineral fertilisation.

\section{Materials and Methods}

\subsection{Site Description and Experimental Design}

The field experiment was established in 2016 in the Field Station of the University of Life Sciences in Lublin $\left(51^{\circ} 13^{\prime} 21^{\prime \prime} \mathrm{N}, 22^{\circ} 37^{\prime} 55^{\prime \prime} \mathrm{E}\right)$. The experiment was assumed as one-factor in the arrangement of completely randomised blocks, in 3 replications. The experiment was located on mineral soil with the 
granulometric composition of silty loam: $18.5 \%$ sand, $1.0-1.1 \mathrm{~mm} ; 74.0 \%$ silt, $0.1-0.02 \mathrm{~mm}$ and $7.5 \%$ clay, $<0.02 \mathrm{~mm}$ [51]. It was very acidic soil $\mathrm{pH}_{\mathrm{KCl}} 4.4$, low in organic matter $\mathrm{C}_{\mathrm{org}}-5.6 \mathrm{~g} \mathrm{~kg}^{-1}$, low in available phosphorus- $-32.6 \mathrm{mg} \mathrm{kg}^{-1}$ and magnesium $-42.8 \mathrm{mg} \mathrm{kg}^{-1}$, and very low in potassium- $44.1 \mathrm{mg} \mathrm{kg}^{-1}$. In spring 2016, six soil sub-samples for soil characterisation were taken from the experimental field, from a depth of $0-20 \mathrm{~cm}$. The samples were air-dried, passed through a $2 \mathrm{~mm}$ sieve, and then mixed to prepare a representative sample (about $0.5 \mathrm{~kg}$ ). The following parameters were determined in the sample: $\mathrm{pH}, \mathrm{C}_{\text {org. }}$, content of available $\mathrm{P}, \mathrm{K}$ and $\mathrm{Mg}$. The soil $\mathrm{pH}$ was determined by potentiometric method (in the suspensions of soil and $1 \mathrm{M}$ solution of $\mathrm{KCl}$ 1:2.5, pH-meter CP 505, Metron; according to PN-ISO 10390:1997) and $C_{\text {org }}$. was determined by the Tiurin method (concentrated sulfuric acid, potassium dichromate, Mohr salt, heating plate CAD H30/45, according to KQ/PB-34). The content of available P and K was determined by the Egner-Riehm method (according to PN-R-04023:1996 and PN-R-04022:1996 + Az1:2002), after extraction with calcium lactate (using P-Spectrophotometer GENESYS 6, K-flame photometer Sherwood 410). The Mg content was determined using Spectrometer AS3 after extracting from the soil with $\mathrm{CaCl}_{2}$ solution (by the Schachtschabel method, according to PN-R-04020:1996 + Az1:2004). For these extraction methods, refer to the limit numbers defining the degree of soil richness in $\mathrm{P}, \mathrm{K}$ and $\mathrm{Mg}$ used in Chemical and Agricultural Stations in Poland. Winter rapeseed had previously been cultivated in this field. For the rapeseed crop, mineral fertilisation was applied as follows $\left(\mathrm{kg} \mathrm{ha}^{-1}\right)$ : N-240, $\mathrm{P}-53, \mathrm{~K}-150, \mathrm{~S}-20$. Organic fertilisation had not been used for at least 10 years.

The experiment includes the following treatments: (1) $\mathrm{O}$ (control)—no fertilising, (2) NPK-mineral fertilising with the following doses $\left(\mathrm{kg} \mathrm{ha}^{-1}\right)$ : N-150, P-53.0, K-105, (3) POF1-agricultural biogas plant digestate in a dose of $30 \mathrm{~m}^{3} \mathrm{ha}^{-1}$ and (4) POF2-agricultural biogas plant digestate in a dose of $60 \mathrm{~m}^{3}$ $\mathrm{ha}^{-1}$. The dose of digestate was determined taking into account the permissible amount of nitrogen which, according to the Act on 'Fertilisers and Fertilisation', can be introduced once with natural fertilisers [52]. The following amount of dry matter was brought with the higher dose of digestate, in subsequent years of experiment (in $\mathrm{t} \mathrm{ha}^{-1}$ d.w.): 2016-19.3, 2017-53, 2018-56. The following amount of N, P and $\mathrm{K}$ was brought with these doses (in $\mathrm{kg} \mathrm{ha}^{-1}$ ): 2016-39, 9, 22, 5; 2017-159, 58, 61; 2018-174, 58, 69 .

Switchgrass cultivar Alamo was planted in the first ten days of May 2016. The distance between rows was $0.90 \mathrm{~m}$, while the spacing between plants within a row was $0.4 \mathrm{~m}$. The area of a single plot was $15 \mathrm{~m}^{2}$. Plots were $3 \mathrm{~m}$ wide and $5 \mathrm{~m}$ long. Switchgrass was propagated vegetatively. Rhizome cuttings obtained from the Department's own plantation were used for planting.

In the year when the experiment was established (2016), due to slow plant growth and the very small amounts of biomass produced, only half of the intended mineral fertiliser doses and half of the assumed digestate dose $\left(15 \mathrm{~m}^{3} \mathrm{ha}^{-1}\right.$ and $30 \mathrm{~m}^{3} \mathrm{ha}^{-1}$, respectively) were applied. In the second (2017) and the third (2018) years, full doses of the assumed mineral fertilisers and digestate were used. Switchgrass was fertilised when it broke dormancy (12-15 May). Fertilisers were incorporated by disking using petrol tiller. Phosphate and potassium fertiliser were applied once in the whole dose ( $\mathrm{P}$-triple superphosphate, $\mathrm{K}$-potassium salt $60 \% \mathrm{~K}_{2} \mathrm{O}$ ). Nitrogen was split-applied, $75 \mathrm{~kg} \mathrm{~N} \mathrm{ha}^{-1}$ was applied at the start of the growing period and another $75 \mathrm{~kg} \mathrm{~N} \mathrm{ha}^{-1}$ was applied just before canopy closure. Nitrogen was applied in the form of ammonium nitrate $(34 \% \mathrm{~N})$. In the first years after switchgrass planting, plant care treatments were also performed by weeding of inter-rows to control the number of weeds emerging in the culture. Table 1 summarises the dates of the various activities performed in the experiment.

The digestate used in the experiment comes from the agricultural biogas plant located in the Lubelskie voivodeship. The following feedstock were used for energy production: corn silage (70\%), sugar bagasse beet $(15 \%)$, pomace of fruit $(5 \%)$, waste from dairy $(5 \%)$ and manure $(5 \%)$. Each year, samples from the digestate batch were collected and used to determine dry weight content (by weight method, according to CLA/PSO/13/2013), total organic carbon content (by spectrometry method, according to CLA/SR/26/2012), total nitrogen content (by the Kjeldahl method, according 
to CLA/PSO/13/2013, using Tecator Digestor Auto 20 firmy FOSS and Kjeltec 2300 firmy FOSS) and the content of the following elements: P (by spectrophotometry method, according to CLA/PLC/28 Spektrofotometer Shimadzu 1800), K, Ca, Mg, Zn, Fe, Cu, Mn, Pb, Ni, Cr, Cd (by Atomic Absorption Spectrometry with flame atomisation, after mineralisation with $\mathrm{HNO}_{3}(\mathrm{~V})$, using the CEM, Model: Mars Xpress Varian and SpektrAA 280FS model with SPS-3 autosampler and SIPS diluter) (Table 2). The assays were performed in the Agro-environmental Laboratory of the University of Life Sciences in Lublin.

Table 1. Activities performed in the experiment.

\begin{tabular}{cccc}
\hline \multirow{2}{*}{ Activity } & \multicolumn{3}{c}{ Year of the Experiment } \\
\cline { 2 - 4 } & $\mathbf{2 0 1 6}$ & $\mathbf{2 0 1 7}$ & $\mathbf{2 0 1 8}$ \\
\cline { 2 - 4 } Mineral fertilisation & 24 April & 13 May & 10 May \\
Planting & 29 April & - & - \\
Biogas digestate application & 25 May & 15 May & 12 May \\
Mineral nitrogen application & 27 May & 30 May & 28 May \\
Weed control & 14 June & - & - \\
First cut & Only One on 16 November & 13 July & 10 July \\
Second cut & & 10 October & 14 October \\
\hline
\end{tabular}

Table 2. Properties of biogas digestate (mean $\pm \mathrm{SE}, n=3$ ).

\begin{tabular}{|c|c|c|c|}
\hline \multirow{2}{*}{ Parameters } & \multicolumn{3}{|c|}{ Years } \\
\hline & 2016 & 2017 & 2018 \\
\hline Dry matter $\left(\mathrm{g} \mathrm{kg}^{-1}\right)$ & $42.9 \pm 1.72$ & $62.4 \pm 3.12$ & $65.6 \pm 3.94$ \\
\hline $\mathrm{pH}\left(\right.$ in $\left.1 \mathrm{~mol}^{-1} \mathrm{KCl}\right)$ & $7.8 \pm 0.39$ & $8.2 \pm 0.35$ & $8.5 \pm 0.39$ \\
\hline$C_{\text {org }}\left(\mathrm{g} \mathrm{kg}^{-1}\right)$ & $343.8 \pm 15.5$ & $339.0 \pm 11.9$ & $357.0 \pm 15.0$ \\
\hline $\mathrm{N}_{\text {tot. }}\left(\mathrm{g} \mathrm{kg}^{-1}\right)$ & $2.0 \pm 0.07$ & $3.0 \pm 0.12$ & $3.1 \pm 0.15$ \\
\hline $\mathrm{C}: \mathrm{N}$ & $17.19 \pm 0.62$ & $11.30 \pm 0.46$ & $11.52 \pm 0.05$ \\
\hline $\mathrm{P}\left(\mathrm{mg} \mathrm{kg}^{-1}\right)$ & $460 \pm 18.8$ & $1090 \pm 39.2$ & $1040 \pm 55.1$ \\
\hline $\mathrm{K}\left(\mathrm{mg} \mathrm{kg}^{-1}\right)$ & $1167 \pm 61.8$ & $1155 \pm 54.3$ & $1225 \pm 53.0$ \\
\hline $\mathrm{Ca}\left(\mathrm{mg} \mathrm{kg}^{-1}\right)$ & $552.5 \pm 23.8$ & $1140 \pm 58.1$ & $1900 \pm 100.7$ \\
\hline $\mathrm{Mg}\left(\mathrm{mg} \mathrm{kg}^{-1}\right)$ & $366.5 \pm 18.7$ & $131.5 \pm 6.4$ & $272 \pm 14.1$ \\
\hline $\mathrm{Na}\left(\mathrm{mg} \mathrm{kg}^{-1}\right)$ & $498.3 \pm 16.9$ & $536.2 \pm 23.1$ & $597.5 \pm 23.3$ \\
\hline $\mathrm{Cu}\left(\mathrm{mg} \mathrm{kg}^{-1}\right)$ & $7.00 \pm 0.27$ & $18.7 \pm 0.94$ & $12.5 \pm 0.54$ \\
\hline $\mathrm{Zn}\left(\mathrm{mg} \mathrm{kg}^{-1}\right)$ & $44.2 \pm 2.25$ & $71.8 \pm 3.50$ & $93.9 \pm 4.40$ \\
\hline $\mathrm{Fe}\left(\mathrm{mg} \mathrm{kg}^{-1}\right)$ & $371 \pm 21.9$ & $688 \pm 1.72$ & $699.5 \pm 37.9$ \\
\hline $\operatorname{Mn}\left(\mathrm{mg} \mathrm{kg}^{-1}\right)$ & $31.5 \pm 1.92$ & $72.2 \pm 37.8$ & $96.5 \pm 6.8$ \\
\hline $\mathrm{Pb}\left(\mathrm{mg} \mathrm{kg}^{-1}\right)$ & $<0.1 \pm 0.00$ & $<0.1 \pm 0.00$ & $<0.1 \pm 0.00$ \\
\hline $\mathrm{Ni}\left(\mathrm{mg} \mathrm{kg}^{-1}\right)$ & $<0.1 \pm 0.00$ & $<0.1 \pm 0.00$ & $<0.1 \pm 0.00$ \\
\hline $\mathrm{Cr}\left(\mathrm{mg} \mathrm{kg}^{-1}\right)$ & $<0.1 \pm 0.00$ & $<0.1 \pm 0.00$ & $<0.1 \pm 0.00$ \\
\hline $\mathrm{Cd}\left(\mathrm{mg} \mathrm{kg}^{-1}\right)$ & $0.20 \pm 0.01$ & $0.27 \pm 0.02$ & $0.18 \pm 0.01$ \\
\hline
\end{tabular}

\subsection{Meteorological Conditions}

The weather conditions during the research period are shown in Figure 1. Based on the meteorological data, the Selyaninov hydrothermal coefficient was calculated (Figure 2), according to the following formula: $\mathrm{k}=(\mathrm{p} \times 10) / \Sigma \mathrm{t}$, where: $\mathrm{p}$ is the sum of monthly precipitation $(\mathrm{mm})$ and $\Sigma \mathrm{t}$ is the sum of average daily temperatures from a month $\left({ }^{\circ} \mathrm{C}\right)$. Designations for ranges of coefficient values were adopted according to the scale developed by Skowera et al. [53]. 

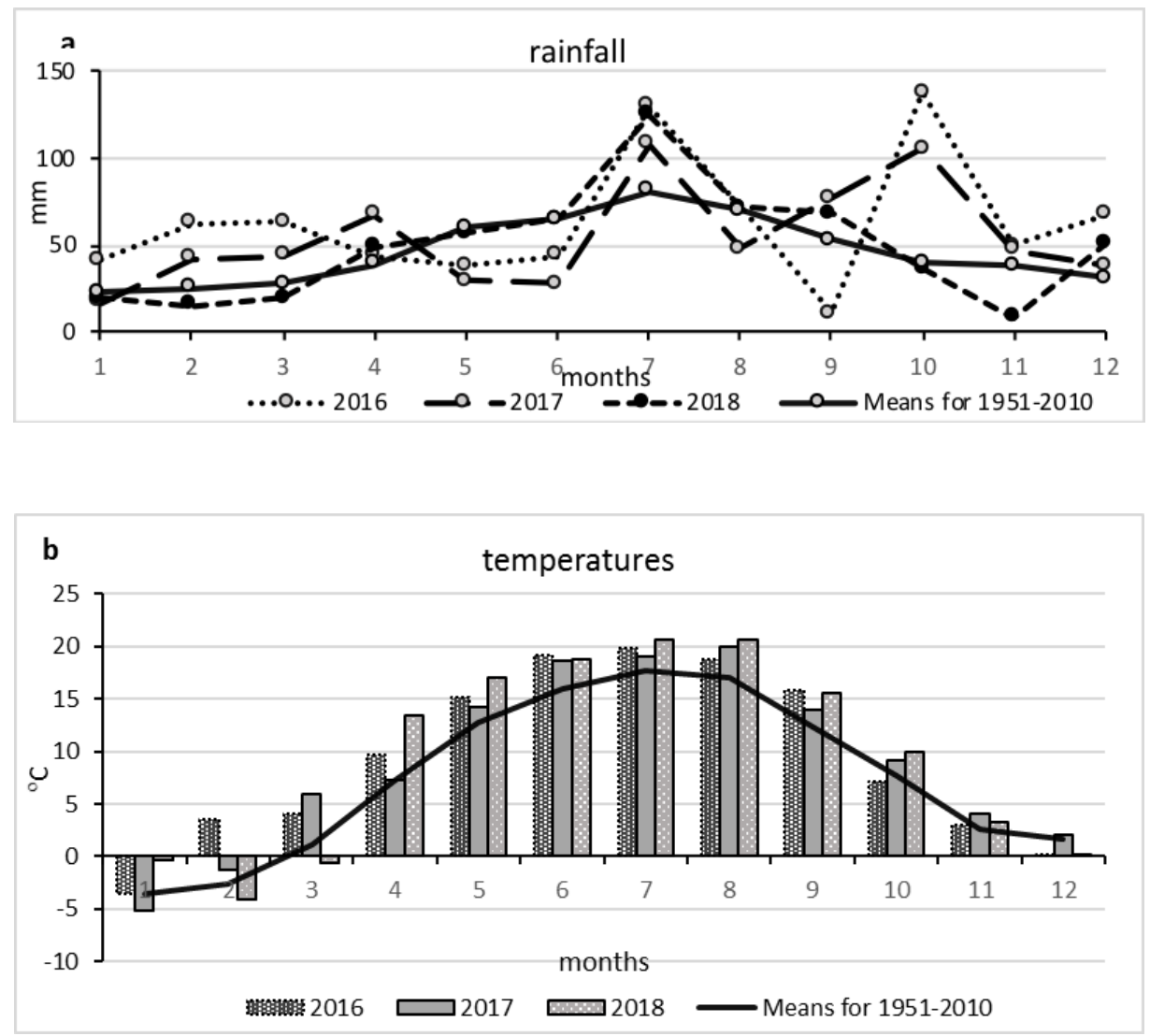

Figure 1. Rainfall (a) and air temperature (b) as compared to the long-term means (1951-2010), according to the Meteorological Station in Felin, Poland.

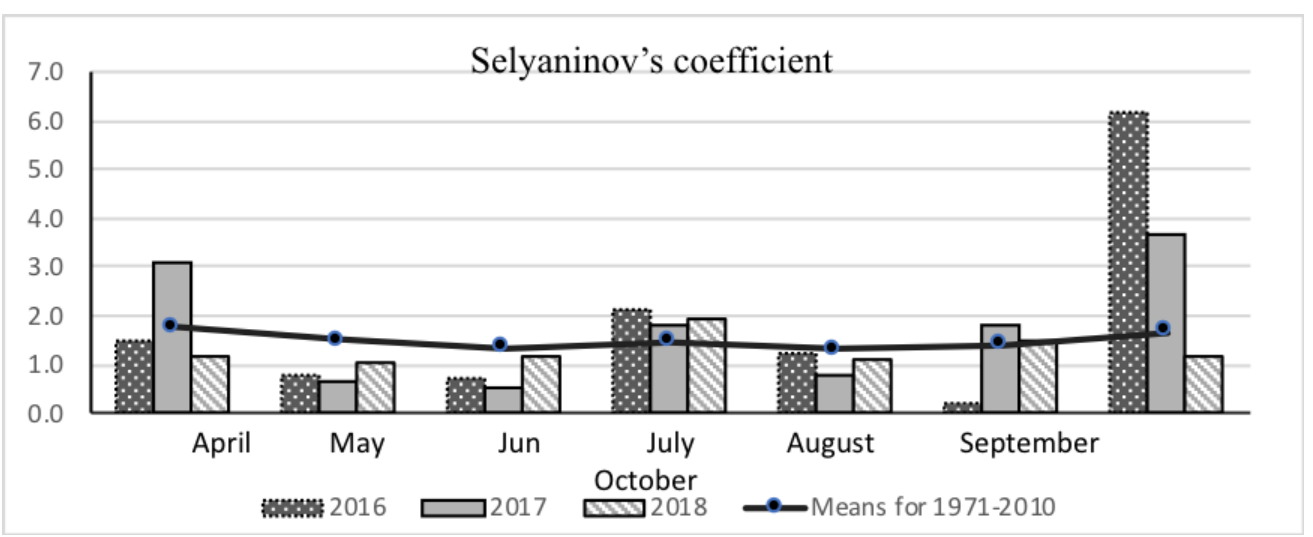

Figure 2. Selyaninov's coefficient for vegetation period (April-October) compared to the long-term averages (1951-2010) according to the Meteorological Station in Felin, Poland.

The amount of rainfall in the first and second growing seasons was lower than the long-term average in May and June. For every year of the experiment, particularly abundant rainfall was recorded in July. The sum of rainfall for the period April-October was similar for three growing seasons and was higher in comparison to the long-term average. In 2016, very low rainfall was recorded in September. The Selyaninov index indicates that for all three growing seasons, the period from June to September, except for July, was dry or rather dry. July was quite moist in every growing season. The temperature sum in the period from April to October ranges from $3131^{\circ} \mathrm{C}$ in the second growing season to $3554{ }^{\circ} \mathrm{C}$ in the third growing season, while the long-term average was $2782^{\circ} \mathrm{C}$. 


\subsection{Measurements}

\subsubsection{Biomass Yield and Morphological Traits}

In the first year, the plants were harvested at the end of switchgrass vegetation, in the second half of November. In 2017 and 2018, the plant harvest was conducted on two dates: (1) First half of July, (2) first half of October (Table 1). The first cut was conducted before the onset of the generative phase. In plant biomass harvested in 2017 and 2018 (on the first and second cut date), the following measurements were made: number of tillers per plant, tiller height, dry matter content, percentage share of leaves in the biomass, fresh weight yield and dry weight yield. Before harvest, two plants were taken separately from each plot. The plants were weighed, and the number of tillers was determined. Then, 20 tillers were randomly selected, and their height was measured. To determine the proportion of leaves and stems, 4 tillers were selected, and the leaves were separated from the stem and weighed. The leaves and stems were finely cut and dried, first for 4 days at room temperature and then for $4 \mathrm{~h}$ in a dryer at $105^{\circ} \mathrm{C}$. Then the samples were weighed, and the proportion of leaves and stems was calculated. One tiller per plot was also selected for determination of dry matter content by the oven-drying method. The remaining biomass of two harvested plants was finely cut, air-dried and was used for laboratory analysis. After harvest, the yield of fresh (by the gravimetric method) and dry switchgrass weight from each plot was determined (taking into account the weight of the plant taken for determinations).

\subsubsection{Laboratory Analysis}

Representative dry biomass samples were ground in a laboratory mill and stored in sealed jars for analysis. Then, the content of dry matter (oven-drying method), crude ash (incineration in a muffle furnace FCF $22 \mathrm{SM}$ Czylok at a temperature of approximately $\left.550^{\circ} \mathrm{C}\right)$ and crude fibre $\left(\mathrm{H}_{2} \mathrm{SO}_{4} 0.13 \mathrm{~mol} / \mathrm{L}\right.$, $\mathrm{KOH} 0.23 \mathrm{~mol} / \mathrm{L}$, Fibre Analyzer Ankom 220), fat content (Fat extractor (Soxhlet apparatus) SER 148 Solvent Extraction Unit, Velp ${ }^{\circledR}$ Scientifica) and crude protein (by the Kjeldahl method, $\mathrm{H}_{2} \mathrm{SO}_{4}, \mathrm{HCL}$, using UDK 132 SemiAutomatic Distillation Unit, Velp ${ }^{\circledR}$ Scientifica) content were determined in the switchgrass samples. In biomass, the content of acid detergent fibre (ADF), neutral detergent fibre (NDF) and ADL (lignin) fraction were also determined (Fibre Analyzer Ankom 220). The content of dry matter, ash, crud protein, crud fat, and ADF and ADL were determined using standard analytical Association of Official Analytical Chemists (AOAC) procedures [54] (procedure numbers 934.01, 942.05, 954.01, 920.39 and 973.18, respectively). Neutral detergent fibre (NDF) and crude fibre were determined according to Van Soest et al. [55]. Hemicellulose content was calculated from the difference between NDF and ADF, while cellulose content was calculated from the difference between ADF and lignin. The analyses were carried out in the laboratory of the Institute of Animal Nutrition and Bromatology, University of Life Sciences in Lublin.

In dry biomass samples, the content of macronutrients, i.e., phosphorus (by spectrophotometry according to CLA/PLC/28, Spektrofotometr Shimadzu 1800), potassium, magnesium, calcium and sodium (by Atomic Absorption Spectrometry with flame atomisation, after mineralisation with $\mathrm{HNO}_{3}$ (V), using CEM, Model: Mars Xpress Varian and SpektrAA 280FS model with SPS-3 autosampler and SIPS diluter, according to CLA/ASA/2), were determined. The results were converted to dry weight. The analyses were carried out at the Central Agroecological Laboratory of the University of Life Sciences in Lublin.

After the experiment was completed, in November 2018, soil samples were taken from each plot. The sub-samples were taken from a 0-20 cm layer using Egner's soil sampler. Five subsamples from each plot were taken and mixed to obtain a representative $(1 \mathrm{~kg})$ soil sample from each plot. The soil samples were homogenised, air-dried, and passed through a 2-mm sieve. The following parameters were determined in the samples collected: $\mathrm{pH}_{\mathrm{KCl}}$, (by potentiometric method), $\mathrm{C}_{\text {org }}$, by Tiurin method, content of available phosphorus and potassium (by the Egner-Riehm method) and available magnesium (by the Schachtschabel method). Determination were performed according to the 
methods described above (in Section 2.1. Site Description and Experimental Design). Content of total nitrogen was determined by the Kjeldahl method (KjelFlex K-360, BUCHI, according to KQ/PB-42). Hydrolytic acidity (Hh) was determined by the Kappen method (PN-R-04027:1997, KQ/PB-36). The air-dried soil sample $(40 \mathrm{~g})$ was treated with $100 \mathrm{~cm}^{3}$ of $0.5 \mathrm{~mol} \mathrm{dm}^{-3} \mathrm{C}_{4} \mathrm{H}_{6} \mathrm{CaO}_{4}$ solution. The suspension was shaken in a rotary shaker and filtrated. The filtrates were titrated with $0.1 \mathrm{~mol}$ $\mathrm{dm}^{-3} \mathrm{NaOH}$ solution in the presence of phenolphthalein indicator. Hydrolytic acidity values were calculated from the amount of $\mathrm{NaOH}$ solution consumed. The exchangeable cations (EAC) were extracted from soil with $1 \mathrm{M}$ solution of $\mathrm{C}_{2} \mathrm{H}_{7} \mathrm{NO}_{2}$. The analysed elements in the resulting extracts were determined by using Flame Fotometer Sherwood 410 (KQ/PB-08). Cation exchange capacity (CEC) and the sorption complex saturation with exchangeable cations (BS) percentage were then calculated as follows: $\mathrm{CEC}=\mathrm{Hh}+\mathrm{EAC}$ and $\mathrm{BS}(\%)=(\mathrm{EAC} / \mathrm{CEC}) \times 100$. The assays were performed at the laboratory of the Regional Chemical and Agricultural Station in Lublin.

\subsection{Statistical Analysis}

The results were statistically analysed by an analysis of variance using STATISTICA 13 PL software (Tulsa, USA). A three-way analysis of variance (ANOVA) was carried out to determine the effect of year, cut date and fertiliser treatment on the variability of switchgrass yield, nutritional value and mineral composition. Year, fertiliser treatment and cut date were considered fixed effects. Replication was considered a random effect. Prior to analysis of variance, the Shapiro-Wilk test was used to determine whether the variables had a normal distribution [56]. The data of the features which did not have a normal distribution were log-transformed and analysis of variance was carried out using the transformed data. The effects of year, cut date and fertiliser treatment, and their interactions, were analysed. A one-way analysis of variance (ANOVA) was carried out to determine the effect of fertilisation treatment on the soil properties. Fertiliser treatment was considered a fixed effect, replication was considered a random effect. Differences between averages were determined using Tukey's test, with $95 \%$ confidence intervals.

\section{Results and Discussion}

\subsection{Biomass Yield and Morphological Traits}

The year, the fertiliser treatment and the cut date significantly differentiated the biomass yield of switchgrass and some of the morphological traits' yield structure (Table 3). On average, biomass yield was significantly higher in 2018 (third year of the study), compared to 2017—second year of the study (Figure 3).

Table 3. Results of analysis of variance (ANOVA) analysis for biomass yield and some morphological traits.

\begin{tabular}{ccccccccc}
\hline & \multicolumn{2}{c}{ Biomass } & \multicolumn{2}{c}{ Number of Panicles per Plant } & \multicolumn{2}{c}{ Panicles Height } & \multicolumn{3}{c}{ Leaf Percentage } \\
\cline { 2 - 9 } & $\mathbf{F}$ & $\mathbf{p}$ & $\mathbf{F}$ & $\mathbf{p}$ & $\mathbf{F}$ & $\mathbf{p}$ & $\mathbf{F}$ & $\mathbf{p}$ \\
\hline Year (Y) & 12.59 & $* *$ & 13.9 & $* *$ & 23.0 & $* * *$ & 0.84 & n.s. \\
Cut (C) & 2437.1 & $* * *$ & 7420.5 & $* * *$ & 1845.0 & $* * *$ & 20.86 & $* * *$ \\
Fertilisation (F) & 116.3 & $* * *$ & 1.0 & n.s. & 131.0 & $* * *$ & 0.79 & n.s. \\
Y $\times$ C & 0.22 & n.s. & 1.3 & n.s. & 23.0 & $* * *$ & 0.99 & n.s. \\
Y $\times$ F & 0.35 & n.s. & 0.3 & n.s. & 0.0 & n.s. & 1.02 & n.s. \\
C $\times$ F & 0.46 & n.s. & 40.2 & $* * *$ & 8.0 & $* *$ & 0.96 & n.s. \\
\hline
\end{tabular}

$p^{*} 0.05,{ }^{* *}<0.01 ;{ }^{* * *}<0.001$, n.s. - not significant. 

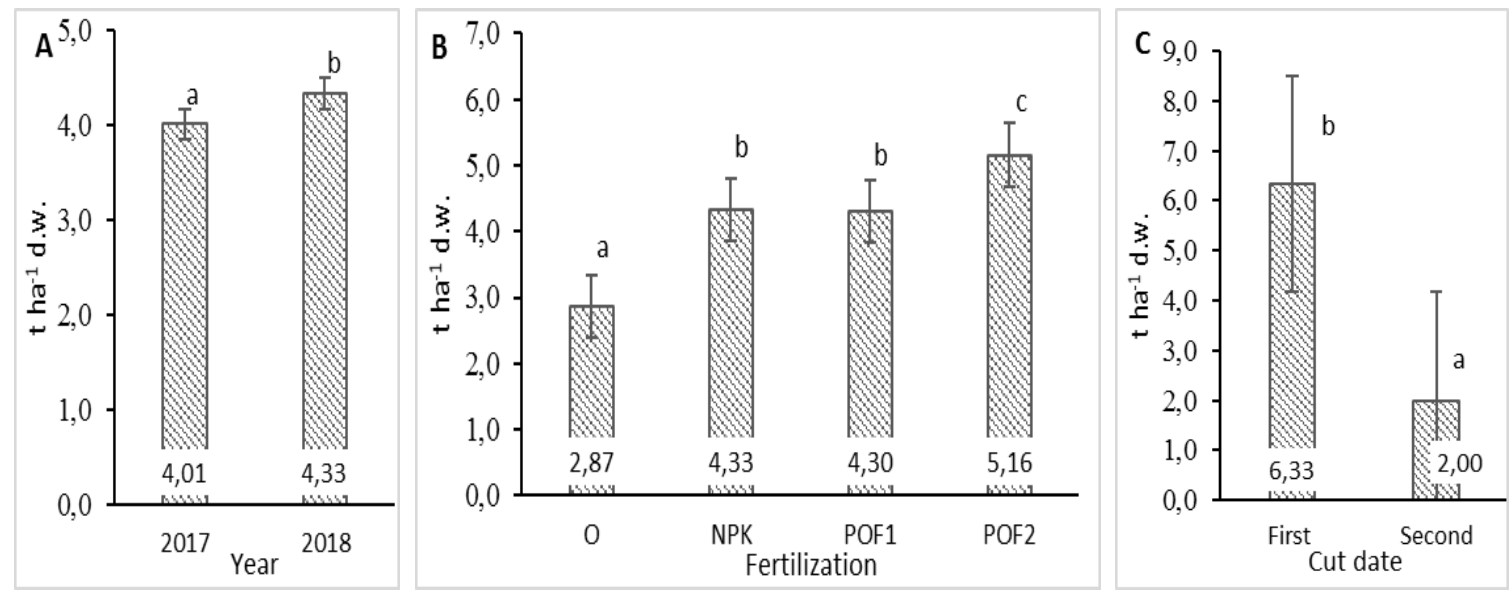

Figure 3. The influence of (A): years, (B): fertiliser treatment, and (C): cut date on the yield of switchgrass biomass. O—no fertilising, NPK—mineral fertilising (respectively N-150, P-53.0, K-105 kg $\mathrm{ha}^{-1}$ ), POF1—biogas digestate $30 \mathrm{~m}^{3} \mathrm{ha}^{-1}$, POF2—biogas digestate $60 \mathrm{~m}^{3} \mathrm{ha}^{-1}$. Bars mean SE, d.w.dry weight.

The biomass of switchgrass of the first cut date (early July) was three times higher than that of the second cut date (second half of October). The significantly lower yield from the second switchgrass cut, is confirmed by the study of Vogel et al. [17]. Similarly, Koshi et al. [57] reported that the second cut in November represents only $28 \%$ of the annual yield of switchgrass.

On average, the lowest annual yield from the two cuts $5.74 \mathrm{t} \mathrm{ha}^{-1} \mathrm{~d} . \mathrm{w}$. (dry weight) within the experiment was obtained on the control without fertilisation. The highest yield in the amount of $10.32 \mathrm{t} \mathrm{ha}^{-1} \mathrm{~d}$.w. was collected from specimens where a higher dose of digestate was applied. However, the yield-forming effect of mineral fertilisation and digestate applied in the amount of $30 \mathrm{~m}^{3} \mathrm{ha}^{-1}$ was similar. The influence of fertiliser treatment on the number of tillers per plant was significant only on the first cut date, where the plants of the control produced the smallest number of shoots (Table 4). The highest number of tillers was observed after mineral fertilisation and after a higher dose of digestate. The plants of the control produced the lowest tillers, and the highest ones were produced after applying a higher dose of the digestate. The higher proportion of leaves in switchgrass biomass, about $74 \%$, was observed on the second cut date, in comparison to the first cut - 30\%. Rancane et al. [48] also reported a greater percentage of leaves in the second cut of reed canary grass and festulolium.

Table 4. The influence of cut date and fertiliser treatment on switchgrass morphological traits and nutrient content. Means followed by the same letter are not statistically different at the $\alpha=0.05$ level. Small letters for cut date $\times$ fertilization, capital letters for years. The standard error of the mean is given after the mean $(n=6$, for year, $n=24)$.

\begin{tabular}{|c|c|c|c|c|c|c|c|}
\hline \multirow{2}{*}{$\begin{array}{l}\text { Cut } \\
\text { Date }\end{array}$} & \multirow{2}{*}{ Fertili-sation } & \multirow{2}{*}{$\begin{array}{c}\text { Number of } \\
\text { Tillers per } \\
\text { Plant }\end{array}$} & \multirow{2}{*}{ Height (cm) } & \multicolumn{4}{|c|}{ Content in Switchgrass Biomass ( $\mathrm{g} \mathrm{kg}^{-1}$ d.w.) } \\
\hline & & & & Crude Ash & Crude Protein & Crude Fat & Crude Fibre \\
\hline \multirow{4}{*}{ First } & $\mathrm{O}$ & $110^{\mathrm{b}} \pm 3.81$ & $92.9^{\mathrm{d}} \pm 1.32$ & $55.5^{\mathrm{a}} \pm 0.40$ & $80.3^{\mathrm{ab}} \pm 0.37$ & $25.8^{\mathrm{d}} \pm 1.40$ & $351.6^{\mathrm{c}} \pm 2.44$ \\
\hline & NPK & $152^{\mathrm{d}} \pm 2.49$ & $107.2^{\mathrm{e}} \pm 1.98$ & $61.2^{\mathrm{b}} \pm 0.43$ & $106.2^{\mathrm{e}} \pm 0.59$ & $23.7^{\mathrm{cd}} \pm 1.06$ & $352.5^{c} \pm 3.52$ \\
\hline & POF1 & $126^{c} \pm 6.12$ & $111.0^{\mathrm{ef}} \pm 2.00$ & $65.9^{c} \pm 0.38$ & $86.2^{\mathrm{bc}} \pm 0.87$ & $23.8^{\mathrm{c}} \pm 0.75$ & $351.1^{\mathrm{c}} \pm 3.81$ \\
\hline & POF2 & $157^{\mathrm{d}} \pm 6.17$ & $113.8^{\mathrm{f}} \pm 2.08$ & $65.5^{c} \pm 0.38$ & $92.0^{\mathrm{cd}} \pm 1.11$ & $20.6^{\mathrm{b}} \pm 0.61$ & $346.6^{c} \pm 4.30$ \\
\hline \multirow{4}{*}{ Second } & $\mathrm{O}$ & $20^{\mathrm{a}} \pm 0.98$ & $71.1^{\mathrm{a}} \pm 0.97$ & $122.6^{\mathrm{g}} \pm 1.30$ & $73.3^{\mathrm{a}} \pm 0.64$ & $13.0^{\mathrm{a}} \pm 0.73$ & $321.3^{\mathrm{b}} \pm 7.50$ \\
\hline & NPK & $15^{\mathrm{a}} \pm 0.76$ & $77.7^{b} \pm 0.82$ & $92.8^{\mathrm{d}} \pm 1.17$ & $108.1^{\mathrm{e}} \pm 5.86$ & $14.3^{\mathrm{a}} \pm 0.36$ & $303.3^{a} \pm 2.83$ \\
\hline & POF1 & $18^{\mathrm{a}} \pm 0.43$ & $81.5^{c} \pm 0.72$ & $117.4^{\mathrm{f}} \pm 1.87$ & $106.5^{\mathrm{e}} \pm 1.35$ & $14.8^{\mathrm{a}} \pm 0.51$ & $325.8^{b} \pm 3.58$ \\
\hline & POF2 & $16^{\mathrm{a}} \pm 0.67$ & $84.1^{\mathrm{C}} \pm 0.87$ & $106.2^{\mathrm{e}} \pm 1.16$ & $103.5^{\text {de }} \pm 1.58$ & $12.6^{\mathrm{a}} \pm 0.23$ & $317.3^{\mathrm{ab}} \pm 4.27$ \\
\hline \multirow{2}{*}{ Years } & 2017 & $74.0^{\mathrm{A}} \pm 12.4$ & $90.6^{\mathrm{A}} \pm 2.86$ & $86.50^{\mathrm{A}} \pm 5.60$ & $94.25^{\mathrm{A}} \pm 3.00$ & $17.6^{\mathrm{A}} \pm 1.07$ & $340.6^{\mathrm{B}} \pm 4.11$ \\
\hline & 2018 & $79.2^{\mathrm{B}} \pm 13.1$ & $94.2^{B} \pm 3.58$ & $85.20^{\mathrm{A}} \pm 5.00$ & $94.80^{\mathrm{A}} \pm 2.70$ & $18.1^{\mathrm{A}} \pm 1.06$ & $326.8^{\mathrm{A}} \pm 3.84$ \\
\hline
\end{tabular}

$\mathrm{O}-$ no fertilising, NPK—-mineral fertilising (respectively N-150, P-53.0, K-105 kg ha ${ }^{-1}$ ), POF1—biogas digestate $30 \mathrm{~m}^{3} \mathrm{ha}^{-1}$, POF2—biogas digestate $60 \mathrm{~m}^{3} \mathrm{ha}^{-1}$.; d.w.—dry weight. 
The yield of switchgrass depends on variety, fertilisation and harvest system [58]. Although switchgrass is generally considered not to have high requirements for soil fertility, nitrogen fertilisation is recommended to increase and maintain its yields on a good level. Vogel et al. [16] report that after applying a dose of $120 \mathrm{~kg} \mathrm{~N} \mathrm{ha}^{-1}$, they obtained a yield of $10.5-12.6 \mathrm{t} \mathrm{ha}^{-1}$ at a single harvest in the generative phase. On the other hand, in the Lemus et al. [14] study, the yield of switchgrass biomass increased from $3.9 \mathrm{t} \mathrm{ha}^{-1}$ with no nitrogen fertilisation to $5.2 \mathrm{t} \mathrm{ha}^{-1}$ after the application of $224 \mathrm{~kg} \mathrm{ha}^{-1}$ of N. According to Gerutzky et al. [58], the effectiveness of nitrogen fertilisation depends on the date of harvest and the highest yields can be obtained with doses of $135-180 \mathrm{~kg} \mathrm{~N} \mathrm{ha}^{-1}$. In addition, higher nitrogen doses are optimal when harvesting twice. During the single harvest, there is a lower uptake of nitrogen and other nutrients with the harvested biomass, because after the end of the growing season, they are moved from the stems and leaves to the root system and can be used in the next year of cultivation [57]. Brodowska et al. [3] reported that switchgrass uses $\mathrm{K}$ and $\mathrm{P}$ effectively. The reaction of the switchgrass to $\mathrm{K}$ and $\mathrm{P}$ fertilisation is dependent on the content of these elements in the soil. Switchgrass reacts positively to phosphorus fertilisation when the element content of the soil is low [59]. Mohamed et al. [60] observed a significant increase (about 49\%) in switchgrass yield after the introduction of NPK fertilisation compared to the control. This shows the importance of improving soil fertility for a high yield of switchgrass. Biogas digestate can have good fertiliser value because during methane fermentation, changes in the $\mathrm{C}: \mathrm{N}$ ratio occur due to the fact that carbon is absorbed by the resulting biomethane, which increases the nitrogen and mineral content. The resulting forms are much easier to be assimilated by plants, as nitrogen is converted to $\mathrm{NH}_{4}{ }^{+}$. High $\mathrm{NH}_{4}{ }^{+}$content is easily accessible to plants [61]. The control soil had low or very low content of available macroelements. Bringing in a significant amount of easily available nutrients with the digestate biomass significantly increased the yield of switchgrass biomass. At a lower dose of the digestate, switchgrass yield was at a similar level as after NPK fertilisation. The application of a higher dose had a significantly higher yield-forming effect than mineral fertilisation. Nitrogen fertilisation also affected the stock density of tillers and stimulated stem growth in another experiment [62]. We found no research on the effect of digestate on the forage yield of switchgrass, but, Tilvikiene et al. [47] reported that for long-term fertilisation, the organic matter of digestate may play a significant role in the increase in cocksfoot biomass production.

\subsection{Nutritional Value}

Year, but not cut date or fertiliser treatment, had a significant effect on crude fibre content and fibre fractions (Tables 5 and 6).

Table 5. Results of ANOVA analysis for nutritional elements.

\begin{tabular}{ccccccccccc}
\hline & \multicolumn{3}{c}{ Dry Matter } & \multicolumn{2}{c}{ Crude Ash } & \multicolumn{2}{c}{ Crude Protein } & \multicolumn{2}{c}{ Crude Fat } & \multicolumn{2}{c}{ Crude Fibre } \\
\cline { 2 - 12 } & $\mathbf{F}$ & $\mathbf{p}$ & $\mathbf{F}$ & $\mathbf{p}$ & $\mathbf{F}$ & $\mathbf{p}$ & $\mathbf{F}$ & $\mathbf{p}$ & $\mathbf{F}$ & $\mathbf{p}$ \\
\hline Year (Y) & 0.70 & n.s. & 0.70 & n.s. & 0.10 & n.s. & 0.853 & n.s. & 32.7 & $* * *$ \\
Cut (C) & 0.10 & n.s. & 9426.2 & $* * *$ & 14.2 & $* *$ & 143.6 & $* * *$ & 195.6 & $* * *$ \\
Fertilisation (F) & 12.8 & $* * *$ & 119.6 & $* * *$ & 52.7 & $* * *$ & 6.3 & $* *$ & 4.2 & $*$ \\
Y $\times$ C & 0.00 & n.s. & 25.0 & $* * *$ & 0.50 & n.s. & 0.05 & n.s. & 0.0 & n.s. \\
Y $\times$ F & 1.2 & n.s. & 0.50 & n.s. & 0.04 & n.s. & 0.01 & n.s. & 0.2 & n.s. \\
C $\times$ F & 0.90 & n.s. & 196.3 & $* *$ & 10.1 & $* * *$ & 58.4 & $* * *$ & 5.4 & $* *$ \\
\hline
\end{tabular}

$p^{*} 0.05,{ }^{* *}<0.01 ;{ }^{* * *}<0.001$, n.s. - not significant.

A higher content of crude fibre (Table 4) and ADF, hemicellulose and cellulose fractions (Figure 4B,D,E) was found in 2017 as compared to 2018. In this year, the rainfall in May and June was lower than in 2018 (Figure 1). The influence of the year on the other parameters of the feed value of switchgrass biomass was not significant (Table 5). Fibre, i.e., structural carbohydrates, is a 
very important component of the ruminant diet. It is not only a source of energy, but also regulates digestive processes and ensures proper gastrointestinal motility. Significantly more crude fibre and all indicated fractions except cellulose were found in the biomass harvested in the first cut date in comparison with the second cut. The applied fertilisation had no significant impact on the crude fibre content in the biomass from the first cut. On the second cut date, however, the lowest content fibre was found in the plants grown with mineral fertilisation while the highest levels were found in the control plants and in plants fertilised with a lower dose of digestate. Mineral fertilisation favoured the highest content of NDF and hemicellulose fractions in biomass from the first cut. Significantly more NDF fraction was found in the biomass harvested on the second cut date from the plots with a higher dose of digestate than from the control and where mineral fertilisation was applied (Figure 4A).

Table 6. Results for ANOVA analysis for fibre fraction.

\begin{tabular}{ccccccccccc}
\hline & \multicolumn{2}{c}{ NDF } & \multicolumn{2}{c}{ ADF } & \multicolumn{2}{c}{ ADL } & \multicolumn{3}{c}{ Hemicelulose } & \multicolumn{2}{c}{ Celulose } \\
\cline { 2 - 11 } & $\mathbf{F}$ & $\mathbf{p}$ & $\mathbf{F}$ & $\mathbf{p}$ & $\mathbf{F}$ & $\mathbf{p}$ & $\mathbf{F}$ & $\mathbf{p}$ & $\mathbf{F}$ & $\mathbf{p}$ \\
\hline Year (Y) & 120.0 & $* * *$ & 48.3 & $* * *$ & 5.32 & $*$ & 68.0 & $* * *$ & 56.0 & $* * *$ \\
Cut (C) & 873.0 & $* * *$ & 304.2 & $* * *$ & 258.6 & $* * *$ & 592.0 & $* * *$ & 220.0 & $* * *$ \\
Fertilisation (F) & 16.0 & $* * *$ & 10.7 & $* * *$ & 11.51 & $* * *$ & 6.0 & $*$ & 13.0 & $* * *$ \\
Y $\times$ C & 0.0 & n.s. & n.s. & n.s. & 0.00 & n.s. & 0.0 & n.s. & 0.0 & n.s. \\
Y $\times$ F & 1.0 & n.s. & n.s. & n.s. & 0.04 & n.s. & 0.0 & n.s. & 0.0 & n.s. \\
C $\times$ F & 63.0 & $* * *$ & 4.2 & $*$ & 13.09 & $* * *$ & 124.0 & $* * *$ & 2.0 & n.s. \\
\hline
\end{tabular}

$p^{*} 0.05,{ }^{* *}<0.01 ;{ }^{* * *}<0.001$, n.s. - not significant.

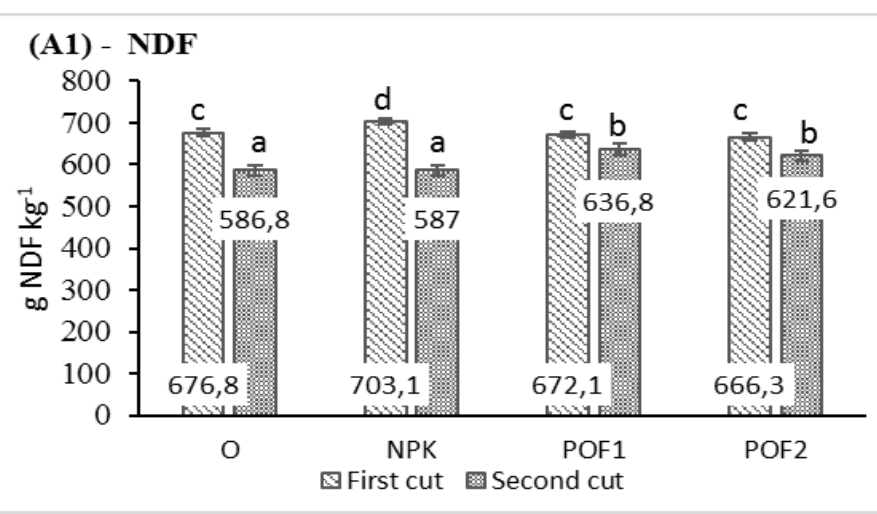

(B1) - ADF

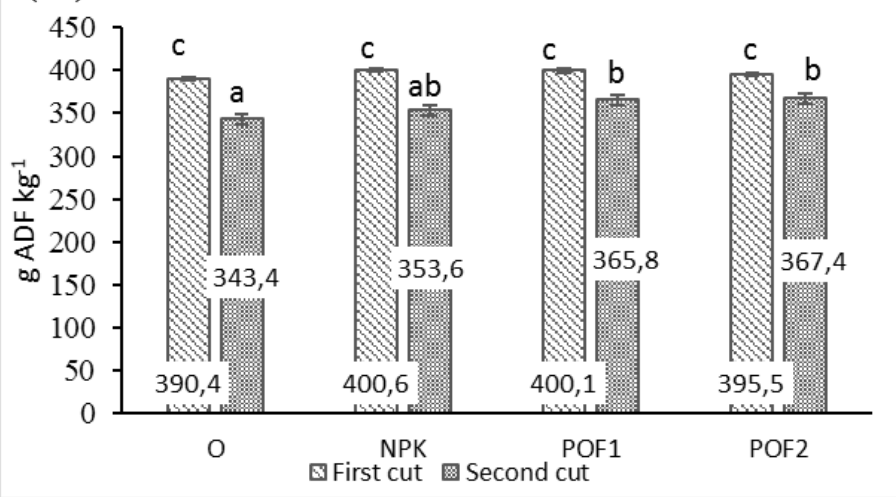

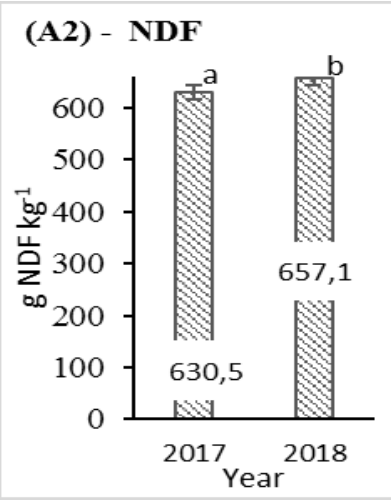

(B2) - ADF

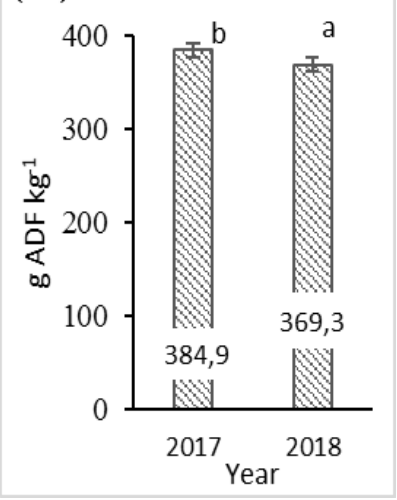

Figure 4. Cont. 

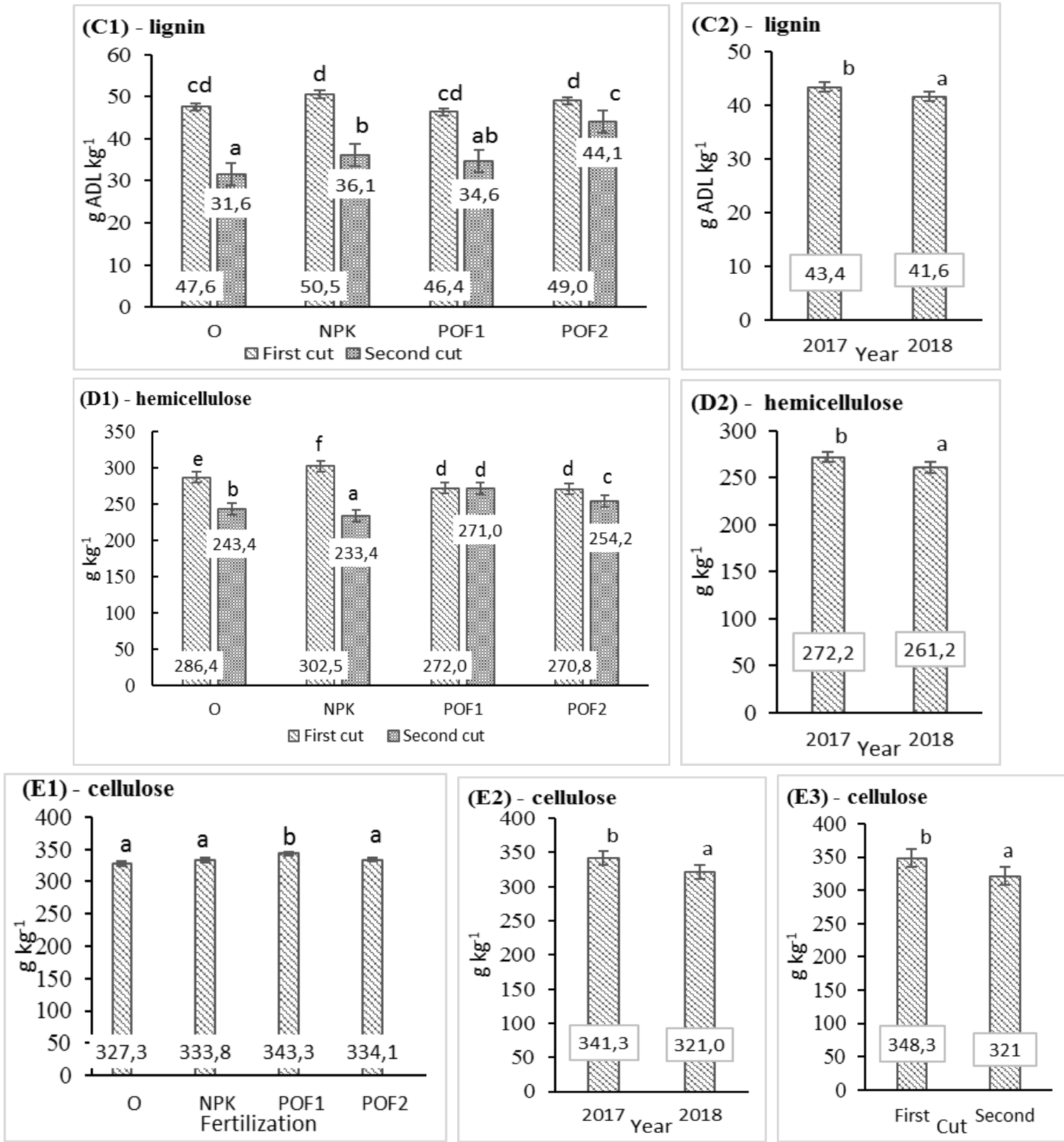

Figure 4. The influence of years, fertilisation and cut date on the fibre fraction: (A1,A2)-NDF (neutral detergent fibre), (B1,B2)—ADF (acid detergent fibre), (C1,C2)—ADL (lignin), (D1,D2)—hemicelulose, (E1,E2,E3)—cellulose. O—no fertilising, NPK - mineral fertilising (respectively N-150, P-53.0, K-105 kg $\mathrm{ha}^{-1}$ ), POF1-biogas digestate $30 \mathrm{~m}^{3} \mathrm{ha}^{-1}$, POF2-biogas digestate $60 \mathrm{~m}^{3} \mathrm{ha}^{-1}$. Bars mean SE.

There is a significant relationship between the NDF content of cattle feed and the digestibility of organic matter. There is also a relationship between NDF and dry matter intake by cattle. In the diet of ruminants, the neutral fibre is particularly important, filling the rumen, providing an energy source for the microorganisms living in it and giving the feed its desired structure. The optimal concentration of $\mathrm{NDF}$ in the dry matter of forage should be from $400 \mathrm{~g} \mathrm{~kg}^{-1}$ to $450 \mathrm{~g} \mathrm{~kg}^{-1}$ [63]. However, if the optimum values are exceeded, the feed will be less digestible, less efficient and more reluctantly consumed by the animals. On the other hand, if the NDF and ADF content of the plant is below the desired amount, this means a low fibre energy content. In Mohamed et al.'s [60] research, both mineral and organic fertilisation increased the content of cellulose in the switchgrass biomass and did not significantly affect the hemicellulose content. The amount of crude fibre for dairy cows, depending on the phase of 
the production cycle and productivity, should be between $18 \%$ and $22 \%$ of the dose, and the amount of NDF and ADF should be between $28 \%$ and $40 \%$ and $19 \%$ and $30 \%$, respectively. These values were exceeded in the switchgrass, especially on the first date. The biomass from the second cut had a fibre fraction content lower than from the first cut. This confirms the opinion of other authors that switchgrass intended for animal feed should be collected during the vegetative phase $[60,64]$.

The fertiliser treatment had a significant effect on the dry matter content in switchgrass biomass (Table 5). Across cut date and year, switchgrass in the control treatment accumulated the most and switchgrass in the mineral fertiliser treatment the least amount of dry matter (Figure 5).

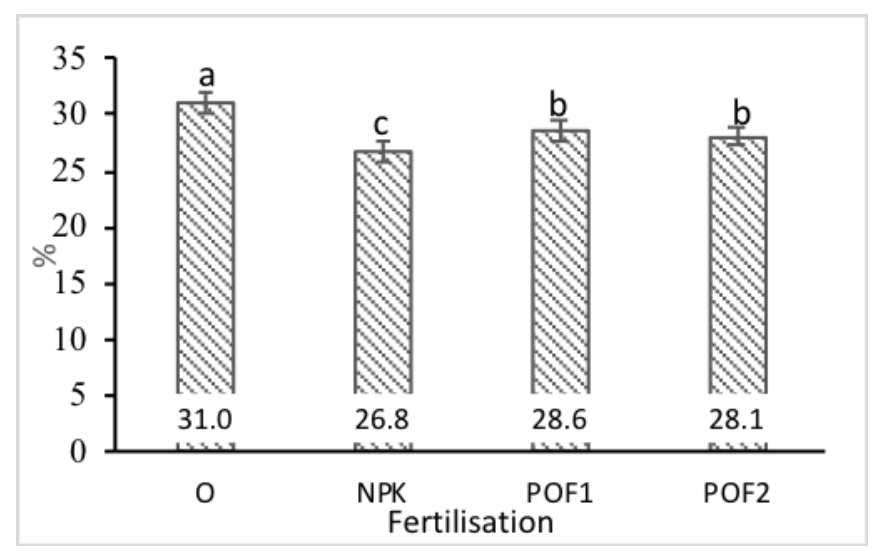

Figure 5. Dry matter content in switchgrass biomass. O-no fertilising, NPK-mineral fertilising (respectively N-150, P-53.0, K-105 kg ha ${ }^{-1}$ ), POF1—biogas digestate $30 \mathrm{~m}^{3} \mathrm{ha}^{-1}$, POF2—biogas digestate $60 \mathrm{~m}^{3} \mathrm{ha}^{-1}$. Bars mean SE.

In each fertiliser treatment, the crude ash content was significantly higher in the biomass from the second cut date. A significant interaction was found between fertilisation and cut dates. The biomass from the control without fertilisation collected in the first date contained less ash than from other fertiliser treatment. In the second cut, a significantly higher ash content was found in the biomass from the plants without fertilisation. Both on the first and second cut date, the ash content in switchgrass after mineral fertilisers was lower compared to that after digestate (Table 4).

The protein content in the biomass of switchgrass from the first cut ranged from 80.3 to $106.2 \mathrm{~g} \mathrm{~kg}^{-1}$, while from the second cut, it ranged from 73.0 to $108.1 \mathrm{~g} \mathrm{~kg}^{-1}$ (Table 4). Generally, it was comparable to or higher than that reported for switchgrass in numerous studies, mainly conducted in the United States [65]. Piłat's et al. [7] research showed that the protein content of switchgrass grown in Poland, harvested at the stage of the beginning of panicle removal, was 76.8-82.2 $\mathrm{g} \mathrm{kg}^{-1}$, while at the stage of the beginning of bloom it was $55.3-71.7 \mathrm{~g} \mathrm{~kg}^{-1}$. Mineral fertilisation as well as a higher dose of digestate significantly increased the protein content in the biomass from the first cut (Table 4) and the protein yield per hectare (Figure 6), compared to the control without fertilisation (Table 4). In the biomass from the second cut, the protein content increased significantly after mineral fertilisation and after digestate, regardless of its dose. An increase in protein content along with an increase in nitrogen fertilisation was also found in other studies $[58,65,66]$. An increase in protein content after digestate from biogas plants was also found in winter wheat [41]. The significant differences in protein content depending on the cut date were observed only after application of the digestate. In these combinations, the biomass from the first cut contained less protein than from the second cut. On the other hand, the protein yield harvested with the first cut was much higher compared to the second cut, in all fertiliser treatments. In the experiment conducted by Giannoulis et al. [67], the switchgrass protein content was at the level of $62.5 \mathrm{~g} \mathrm{~kg}^{-1}$ with low nitrogen fertilisation. According to the authors, this confirms the possibility of growing switchgrass on less fertile soils and producing feed at low inputs. This content is higher than in the straw of wheat $(3.5 \%)$, oats $(4.4 \%)$ or pea $(6.5 \%)$ [68]. 


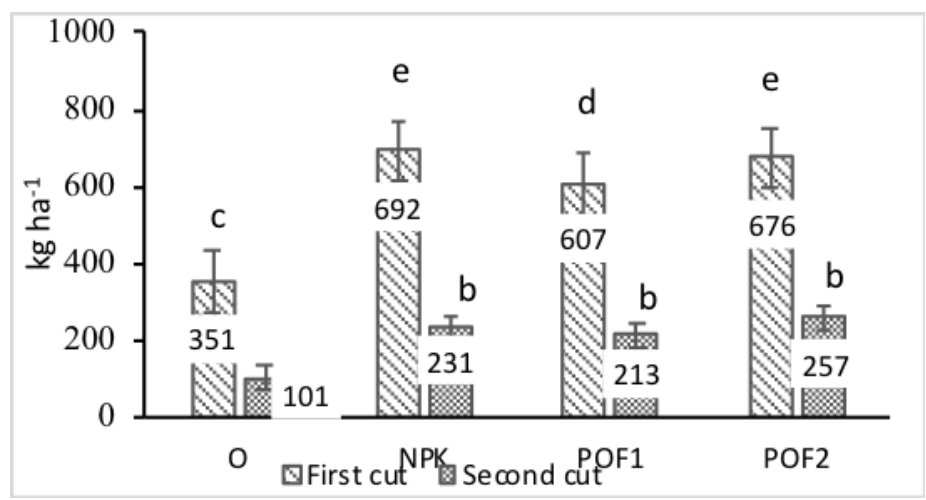

Figure 6. The influence of the cut date and fertilisation on the yield of protein in switchgrass. $\mathrm{O}-$ no fertilising, NPK—-mineral fertilising (respectively N-150, P-53.0, K-105 $\mathrm{kg} \mathrm{ha}^{-1}$ ), POF1—biogas digestate $30 \mathrm{~m}^{3} \mathrm{ha}^{-1}$, POF2-biogas digestate $60 \mathrm{~m}^{3} \mathrm{ha}^{-1}$. Bars mean SE.

The fat content in the biomass of switchgrass from the first cut ranged from 20.6 to $25.8 \mathrm{~g} \mathrm{~kg}^{-1}$ and from the second-from 12.6 to $14.8 \mathrm{~g} \mathrm{~kg}^{-1}$ (Table 4). In the first cut, the least amount of fat was in switchgrass fertilised with a higher dose of the digestate, and the most from the control specimen. On the second cut date, the effect of fertilisation on the fat content of biomass was not significant. In a typical ration for dairy cows, the fat content should be less than $2.5 \%$ of dry matter.

\subsection{Mineral Composition}

The year, the fertiliser treatment and the cut date significantly affected the content of some macroelements (Table 7).

Table 7. Results of ANOVA analysis for the content of macroelements.

\begin{tabular}{cccccccccccc}
\hline & \multicolumn{3}{c}{$\mathbf{P}$} & \multicolumn{2}{c}{$\mathbf{K}$} & \multicolumn{2}{c}{$\mathbf{C a}$} & \multicolumn{1}{c}{$\mathbf{M g}$} & \multicolumn{2}{c}{$\mathbf{N a}$} \\
\cline { 2 - 12 } & $\mathbf{F}$ & $\mathbf{p}$ & $\mathbf{F}$ & $\mathbf{p}$ & $\mathbf{F}$ & $\mathbf{p}$ & $\mathbf{F}$ & $\mathbf{p}$ & $\mathbf{F}$ & $\mathbf{p}$ \\
\hline Year (Y) & 0.02 & n.s. & 22.2 & $* * *$ & 4.73 & $*$ & 14.61 & $* * *$ & 1.90 & n.s. \\
Cut (C) & 2.33 & n.s. & 77.06 & $* * *$ & 302.0 & $* * *$ & 306.1 & $* * *$ & 44.5 & $* * *$ \\
Fertilisation (F) & 3.17 & $*$ & 17.78 & $* * *$ & 0.865 & n.s. & 27.4 & $* * *$ & 4.95 & $* *$ \\
Y x C & 0.09 & n.s. & 9.73 & $* *$ & 1.85 & n.s. & 4.73 & $*$ & 0.01 & n.s. \\
Y x F & 0.19 & n.s. & 9.67 & $* * *$ & 0.99 & n.s. & 2.81 & n.s. & 1.34 & n.s. \\
C x F & 4.92 & $* *$ & 74.31 & $* * *$ & 9.13 & $* * *$ & 41.28 & $* * *$ & 10.4 & $* * *$ \\
\hline
\end{tabular}

The changes in $\mathrm{P}$ content under the influence of fertiliser treatment and the cut date were generally small (Table 8). The least amount of the element was found in the biomass from the control, both on the first and second cut date. Significantly more $\mathrm{P}$ was in the biomass harvested in the second cut from plants where biogas digestate was used. The $\mathrm{K}$ content in switchgrass from the first cut in combination without and with mineral fertilisation was significantly lower than after digestate. An inverse relationship was observed on the second cut date. After biogas digestate, the $\mathrm{K}$ content was significantly lower than in the control or after mineral fertilisation. In the three fertiliser treatments, apart from the control combination, the $\mathrm{K}$ content in the biomass from the first cut was significantly higher than from the second. In general, the $\mathrm{Ca}$ and $\mathrm{Mg}$ content in all fertiliser treatment was significantly higher in the biomass from the second cut. As regards the biomass collected on the first cut date, significantly more $\mathrm{Ca}$ was observed in the specimen with mineral fertilisation compared to the control. On the second cut, the most $\mathrm{Ca}$ was accumulated by switchgrass plants of the control treatment, the least after applying a lower dose of the digestate. 
Table 8. The influence of cut date and fertiliser treatment on the content of macroelements in switchgrass biomass. Means followed by the same letter are not statistically different at the $\alpha=0.05$ level. Small letters for cut date $\times$ fertilization, capital letters for years. The standard error of the mean is given after the mean $(n=6$, for year, $n=24)$.

\begin{tabular}{|c|c|c|c|c|c|c|}
\hline \multirow{2}{*}{ Cut Date } & \multirow{2}{*}{ Fertilisation } & \multicolumn{5}{|c|}{ Macronutrient Content ( $\mathrm{g} \mathrm{kg}^{-1}$ d.w.) } \\
\hline & & $\mathbf{P}$ & $\mathbf{K}$ & $\mathrm{Ca}$ & $\mathrm{Mg}$ & $\mathrm{Na}$ \\
\hline \multirow{4}{*}{ First } & $\mathrm{O}$ & $1.92^{\mathrm{ab}} \pm 0.05$ & $9.15^{\mathrm{a}} \pm 0.43$ & $1.65^{\mathrm{a}} \pm 0.14$ & $1.00^{\mathrm{a}} \pm 0.03$ & $0.35^{\mathrm{ab}} \pm 0.01$ \\
\hline & NPK & $2.15^{\mathrm{abc}} \pm 0.03$ & $14.33^{\mathrm{d}} \pm 0.27$ & $2.26^{\mathrm{b}} \pm 0.07$ & $1.50^{\mathrm{bc}} \pm 0.05$ & $0.48^{c} \pm 0.01$ \\
\hline & POF1 & $2.02^{\mathrm{abc}} \pm 0.35$ & $12.30^{\mathrm{b}} \pm 0.30$ & $1.98^{\mathrm{ab}} \pm 0.05$ & $1.03^{\mathrm{a}} \pm 0.02$ & $0.43^{\mathrm{bc}} \pm 0.02$ \\
\hline & POF2 & $1.99^{\mathrm{abc}} \pm 0.35$ & $14.26^{\mathrm{cd}} \pm 0.20$ & $1.95^{\mathrm{ab}} \pm 0.15$ & $1.02^{\mathrm{a}} \pm 0.04$ & $0.41^{\mathrm{bc}} \pm 0.02$ \\
\hline \multirow{4}{*}{ Second } & $\mathrm{O}$ & $1.80^{\mathrm{a}} \pm 0.24$ & $12.54^{\mathrm{bc}} \pm 0.33$ & $4.51^{\mathrm{d}} \pm 0.23$ & $1.34^{\mathrm{b}} \pm 0.07$ & $0.27^{\mathrm{a}} \pm 0.03$ \\
\hline & NPK & $2.13^{\mathrm{abc}} \pm 0.02$ & $11.40^{\mathrm{b}} \pm 0.48$ & $3.62^{\mathrm{cd}} \pm 0.19$ & $1.62^{\mathrm{cd}} \pm 0.05$ & $0.39^{b} \pm 0.02$ \\
\hline & POF1 & $2.61^{\mathrm{bc}} \pm 0.99$ & $8.67^{\mathrm{a}} \pm 0.58$ & $3.47^{\mathrm{c}} \pm 0.15$ & $1.83^{\mathrm{d}} \pm 0.07$ & $0.34^{\mathrm{ab}} \pm 0.02$ \\
\hline & POF2 & $2.32^{\mathrm{c}} \pm 0.08$ & $9.31^{\mathrm{a}} \pm 0.80$ & $4.06^{\mathrm{cd}} \pm 0.27$ & $2.18^{\mathrm{e}} \pm 0.16$ & $0.28^{a} \pm 0.03$ \\
\hline \multirow{2}{*}{ Years } & 2017 & $2.11^{\mathrm{A}} \pm 0.07$ & $11.01^{\mathrm{A}} \pm 0.52$ & $2.79^{\mathrm{A}} \pm 0.20$ & $1.36^{\mathrm{A}} \pm 0.07$ & $0.36^{\mathrm{A}} \pm 0.02$ \\
\hline & 2018 & $2.03^{\mathrm{A}} \pm 0.07$ & $11.98^{\mathrm{B}} \pm 0.43$ & $3.10^{\mathrm{B}} \pm 0.25$ & $1.52^{\mathrm{B}} \pm 0.10$ & $0.38^{\mathrm{A}} \pm 0.01$ \\
\hline
\end{tabular}

O-no fertilising, NPK-mineral fertilising (respectively N-150, P-53.0, K-105 $\mathrm{kg} \mathrm{ha}^{-1}$ ), POF1—biogas digestate 30

$\mathrm{m}^{3} \mathrm{ha}^{-1}$, POF2-biogas digestate $60 \mathrm{~m}^{3} \mathrm{ha}^{-1}$. d.w.—dry weight.

The use of mineral fertilisation favoured a higher Mg content in the switchgrass from the first cut. In the second cut, a higher Mg content was found after higher doses of digestate. Sodium content was little affected and without clear trends. The total uptake of macroelements, which is the resultant of the biomass yield and component content in the biomass, was the lowest in the control combination. The organic and mineral fertilisers increased total uptake of P, K, Ca and Mg (Figure 7A-D).
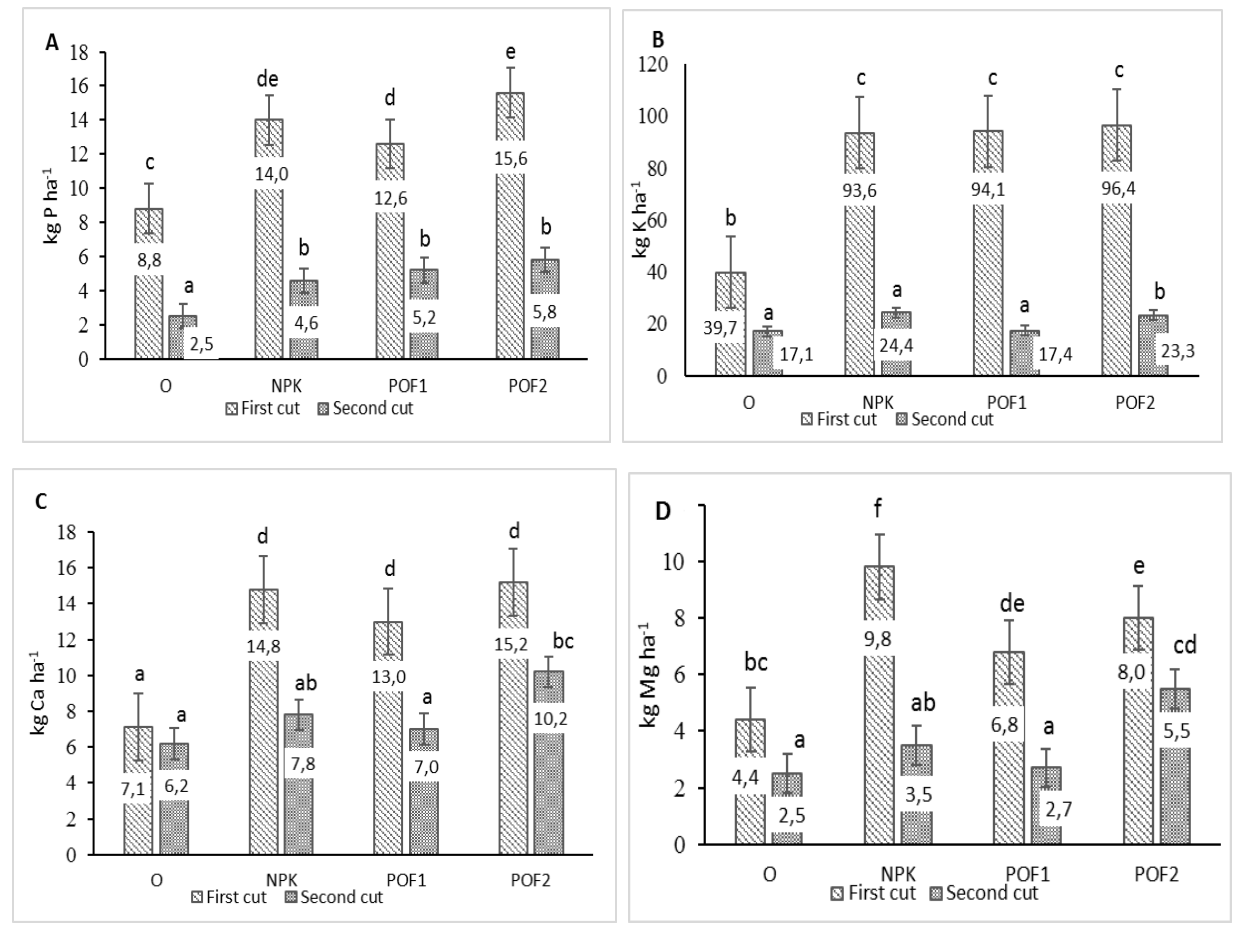

Figure 7. The influence of cut date and fertilisation on the uptake of: (A)—phosphorus, (B) - potassium, (C)—calcium, (D)—magnesium. O—no fertilising, NPK—-mineral fertilising (respectively N-150, P-53.0, $\mathrm{K}-105 \mathrm{~kg} \mathrm{ha}^{-1}$ ), POF1 - biogas digestate $30 \mathrm{~m}^{3} \mathrm{ha}^{-1}$, POF2 - biogas digestate $60 \mathrm{~m}^{3} \mathrm{ha}^{-1}$. Bars mean SE.

Kering et al. [65] observed an increase in the $\mathrm{P}, \mathrm{K}, \mathrm{Ca}$ and $\mathrm{Mg}$ content in the switchgrass biomass under the influence of increasing nitrogen fertilisation. According to Marschner [69], the increase in vigour and growth of plants under the influence of better nitrogen supply may explain the increase 
in $\mathrm{P}, \mathrm{K}$ and $\mathrm{Mg}$. The faster growth associated with higher nitrogen fertilisation may stimulate root development and increase the potential of plants to obtain macroelements from the soil. Moreover, significant amounts of easily assimilable minerals were introduced with the digestate mass [30,70], which probably had an impact on increasing their content in the biomass of switchgrass. Besides the observed beneficial effect of the digestate on the physicochemical properties of the soil, especially the reaction and sorption capacity, determining the availability and uptake of the nutrients by plants, may also be of great importance.

\subsection{Soil Properties}

The three-year application of the tested fertiliser treatment had a significant impact on the soil properties (Table 9). A higher dose of the digestate increased soil $\mathrm{pH}$ from very acid $\mathrm{pH}_{\mathrm{KCl}} 4.5$ to acid $\mathrm{pH}_{\mathrm{KCl}} 4.9$ and decreased hydrolytic acidity. The NPK fertilisation and the lower biogas digestate dose did not influence soil $\mathrm{pH}$. Soil $\mathrm{pH}$ is one of its most important properties, as it regulates to a large extent the availability of minerals that affect the growth and development of plants. At low $\mathrm{pH}(<5.0)$, the availability of macronutrients, i.e., $\mathrm{N}, \mathrm{P}, \mathrm{K}, \mathrm{Ca}, \mathrm{Mg}$, and micronutrients, i.e., $\mathrm{Mo}$, B, is lower for plants. However, the uptake of trace elements, i.e., $\mathrm{Fe}, \mathrm{Mn}, \mathrm{Zn}, \mathrm{Cu}$, is increased. The beneficial effect of the digestate on the reduction of soil acidity was observed by Różyło et al. [30] and by Piatek and Bartkowiak [70]. This is very beneficial as soil acidification is a serious problem worldwide and in Poland about $58 \%$ of soils have an acidic reaction $\mathrm{pH}<5.5$ [71]. The higher rate of biogas digestate was also shown to increase $\mathrm{C}_{\text {org. }}$. content relative to the unfertilised control and mineral fertilisation (Table 9). Biogas digestate can be considered a valuable source of organic matter in plant fertilisation. Studies by other authors confirm the influence of digestate on the increase of organic carbon content in the soil, which is very important for maintaining or improving its fertility [30,72]. During the anaerobic digestion process, the organic matter of the substrates is decomposed and the carbon is converted into $\mathrm{CH}_{4}$ and $\mathrm{CO}_{2}$, as a result of which, the digestate has a narrow $\mathrm{C}: \mathrm{N}$ ratio $[31,61]$ and its application resulted in narrowing the ratio of carbon to nitrogen in the soil in the described experiment. But the lowest value of $\mathrm{C}: \mathrm{N}$ ratio was observed when mineral fertilisation was applied. The C:N ratio has an effect on nitrogen mineralisation. At low C:N ratios less than 20:1, microorganisms quickly mineralise organic nitrogen while releasing inorganic forms, whereas higher $\mathrm{C}: \mathrm{N}$ ratios reduce the rate of mineralisation $[61,73]$.

Table 9. Effect of fertiliser treatments on mean physicochemical soil properties after three years. Means followed by the same letter are not statistically different at the $\alpha=0.05$ level. The standard error of the mean is given after the mean $(n=3)$.

\begin{tabular}{|c|c|c|c|c|}
\hline \multirow{2}{*}{ Parameters } & \multicolumn{4}{|c|}{ Autumn 2018} \\
\hline & $\mathbf{O}$ & NPK & POF1 & POF2 \\
\hline $\mathrm{pH}_{\mathrm{KCL}}$ & $4.5^{\mathrm{a}} \pm 0.20$ & $4.6^{\mathrm{a}} \pm 0.22$ & $4.6^{\mathrm{a}} \pm 0.21$ & $4.9^{\mathrm{b}} \pm 0.23$ \\
\hline $\mathrm{C}_{\text {org }}\left(\mathrm{g} \mathrm{kg}^{-1}\right)$ & $5.7^{\mathrm{a}} \pm 0.24$ & $5.9^{\mathrm{ab}} \pm 0.28$ & $6.2^{\mathrm{bc}} \pm 0.27$ & $6.4^{\mathrm{C}} \pm 0.28$ \\
\hline $\mathrm{N}_{\mathrm{og} .}\left(\mathrm{g} \mathrm{kg}^{-1}\right)$ & $0.64^{\mathrm{a}} \pm 0.02$ & $0.77^{\mathrm{b}} \pm 0.11$ & $0.73^{\mathrm{b}} \pm 0.10$ & $0.76^{\mathrm{b}} \pm 0.11$ \\
\hline C:N & $9.06^{\mathrm{C}} \pm 0.38$ & $7.92^{\mathrm{a}} \pm 0.34$ & $8.08^{\mathrm{ab}} \pm 0.31$ & $8.16^{\mathrm{b}} \pm 0.34$ \\
\hline Hydrolytic acidity $(\mathrm{Hh})\left(\mathrm{mmol} \mathrm{H}^{+} \mathrm{kg}^{-1}\right)$ & $31.5^{\mathrm{b}} \pm 1.74$ & $30.2^{\mathrm{b}} \pm 1.58$ & $30.1^{\mathrm{b}} \pm 1.36$ & $25.1^{\mathrm{a}} \pm 1.31$ \\
\hline Cation exchange capacity $(\mathrm{CEC})\left(\mathrm{mmol}(+) \mathrm{kg}^{-1}\right)$ & $104.1^{\mathrm{a}} \pm 5.83$ & $129.2^{\mathrm{bc}} \pm 6.98$ & $123.5^{\mathrm{b}} \pm 6.05$ & $133.2^{\mathrm{C}} \pm 6.93$ \\
\hline The sum of exchangeable cations (EAC) $\left(\mathrm{mmol}(+) \mathrm{kg}^{-1}\right)$ & $74.0^{\mathrm{a}} \pm 3.48$ & $99.0^{c} \pm 5.05$ & $92.0^{\mathrm{b}} \pm 4.78$ & $108.1^{\mathrm{d}} \pm 5.73$ \\
\hline $\begin{array}{l}\text { Sorption complex saturation with exchangeable cations } \\
\text { (BS) (\%) }\end{array}$ & $71.1^{\mathrm{a}} \pm 3.25$ & $76.6^{\mathrm{b}} \pm 3.68$ & $74.4^{\mathrm{b}} \pm 3.30$ & $81.2^{\mathrm{c}} \pm 4.22$ \\
\hline \multicolumn{5}{|c|}{ Content of available nutrients } \\
\hline $\mathrm{P}\left(\mathrm{mg} \mathrm{kg}^{-1}\right)$ & $34.3^{\mathrm{a}} \pm 1.77$ & $51.1^{\mathrm{b}} \pm 2.30$ & $51.5^{\mathrm{b}} \pm 2.58$ & $52.8^{\mathrm{b}} \pm 2.75$ \\
\hline $\mathrm{K}\left(\mathrm{mg} \mathrm{kg}^{-1}\right)$ & $40.7^{\mathrm{a}} \pm 2.36$ & $55.6^{\mathrm{b}} \pm 3.00$ & $56.4^{\mathrm{b}} \pm 3.22$ & $70.6^{\mathrm{C}} \pm 4.20$ \\
\hline $\mathrm{Mg}\left(\mathrm{mg} \mathrm{kg}^{-1}\right)$ & $43.0^{\mathrm{a}} \pm 2.19$ & $70.0^{c} \pm 4.13$ & $63.0^{\mathrm{b}} \pm 3.28$ & $66.0^{\mathrm{bc}} \pm 3.37$ \\
\hline $\mathrm{Cu}\left(\mathrm{mg} \mathrm{kg}^{-1}\right)$ & $1.4^{\mathrm{a}} \pm 0.06$ & $1.9^{\mathrm{b}} \pm 0.07$ & $1.3^{\mathrm{a}} \pm 0.05$ & $1.9^{\mathrm{b}} \pm 0.08$ \\
\hline $\mathrm{Zn}\left(\mathrm{mg} \mathrm{kg}^{-1}\right)$ & $5.6^{\mathrm{a}} \pm 0.33$ & $6.0^{\mathrm{b}} \pm 0.29$ & $5.8^{\mathrm{ab}} \pm 0.31$ & $7.4^{c} \pm 0.34$ \\
\hline $\mathrm{Fe}\left(\mathrm{mg} \mathrm{kg}^{-1}\right)$ & $903^{\mathrm{ab}} \pm 31.5$ & $933^{c} \pm 34.5$ & $877^{\mathrm{a}} \pm 29.7$ & $914^{\mathrm{b}} \pm 34.6$ \\
\hline $\operatorname{Mn}\left(\mathrm{mg} \mathrm{kg}^{-1}\right)$ & $189.0^{c} \pm 9.07$ & $179.0^{\mathrm{b}} \pm 8.06$ & $171.0^{\mathrm{ab}} \pm 8.04$ & $166.0^{\mathrm{a}} \pm 7.99$ \\
\hline
\end{tabular}

$\mathrm{O}-$ no fertilising, NPK - mineral fertilising (respectively N-150, P-53.0, K-105 $\mathrm{kg} \mathrm{ha}^{-1}$ ), POF1—biogas digestate 30 $\mathrm{m}^{3} \mathrm{ha}^{-1}$, POF2-biogas digestate $60 \mathrm{~m}^{3} \mathrm{ha}^{-1}$. 
The application of mineral fertilisation as well as both doses of the digestate increased the total nitrogen content in the soil and the sorption capacity, the sum of exchangeable alkaline cations and the degree of saturation of the sorption complex with alkaline cations. The higher dose of digestate had the most favourable impact on soil properties. The degree of alkaline saturation is an important indicator of agricultural soil quality. The value of this characteristic below $50 \%$ indicates a degraded soil (fertilisation, crop rotation), at the level of $50 \%-75 \%$, also agrotechnical errors, only values above $85 \%$ indicate a good physicochemical condition of the soil. As emphasised by Brodowski et al. [74] and Cheng et al. [75], this parameter plays a crucial role in the retention of water and nutrients for plants. Cation exchange capacity is important for maintaining adequate quantities of plant-available $\mathrm{Ca}, \mathrm{Mg}$, and $\mathrm{K}$ in soils. The applied fertilisation also influenced the share of cations in the sorption complex, generally decreasing the share of $\mathrm{H}^{+}$ions and increasing slightly the share of $\mathrm{Ca}^{2+}$ ions and more clearly increasing the share of $\mathrm{Mg}^{2+}$ and $\mathrm{K}^{+}$cations (Figure 8). The optimal $\mathrm{Ca}$ to $\mathrm{Mg}$ ratio should be 7:1 [76]. According to Sanik et al. [77], the Ca:Mg ratio has an impact on the solubility of cations in the soil solution. In our studies, the soil was very low in $\mathrm{Mg}$ and although it was not possible to obtain such favourable relations, the introduction of both mineral fertilisation and the digestate, especially a higher dose, resulted in a clear narrowing of the Ca:Mg ratio from 15:1 to 11.5-11.0:1.

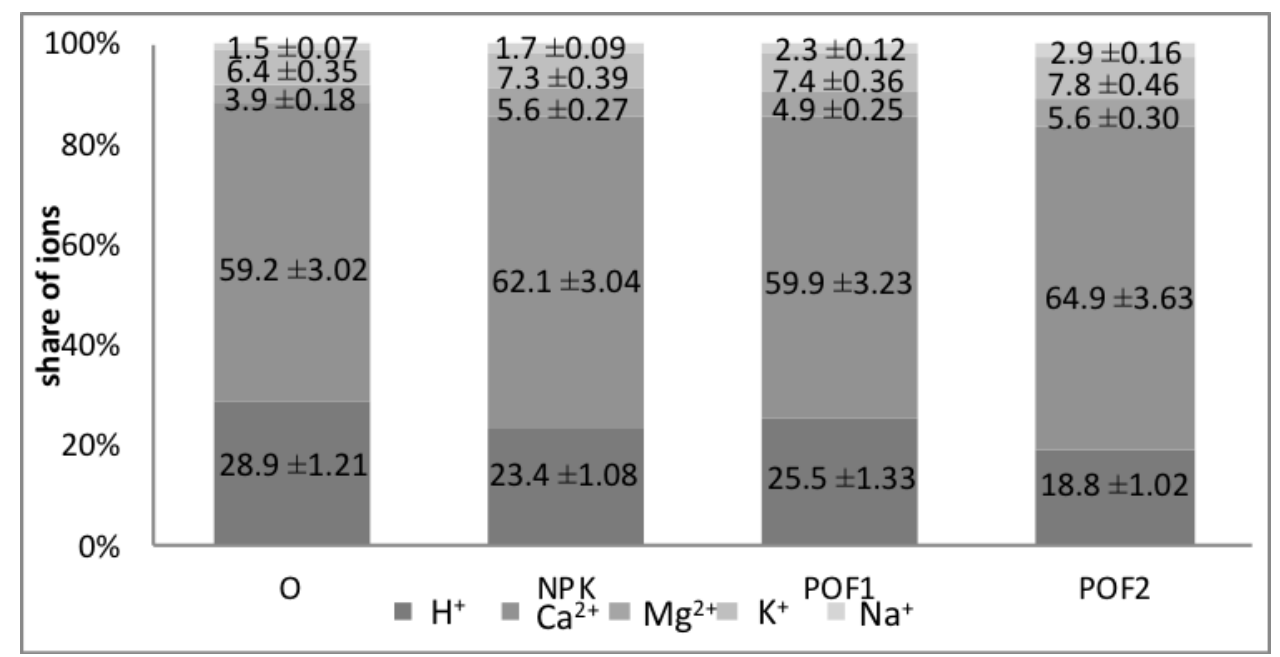

Figure 8. Percentage of ions in the sorption complex. O-no fertilising, NPK-mineral fertilising (respectively N-150, P-53.0, K-105 $\mathrm{kg} \mathrm{ha}^{-1}$ ), POF1—biogas digestate $30 \mathrm{~m}^{3} \mathrm{ha}^{-1}$, POF2—biogas digestate $60 \mathrm{~m}^{3} \mathrm{ha}^{-1}$, (mean $\pm \mathrm{SE}, n=3$ ).

The unfertilised soil was characterised by a low concentration of $\mathrm{P}$ and very low $\mathrm{K}$. All fertiliser treatments increased the content of available forms of $\mathrm{P}$ and $\mathrm{Mg}$ in the soil to the level of average concentration. The $\mathrm{K}$ content increased from very low to low, but only as a result of three years of using a higher dose of the digestate. Changes in the microelement content were less pronounced. An increase in $\mathrm{Cu}$ content was observed under mineral fertilisation and under the higher dose of the digestate. An increase in $\mathrm{Zn}$ content was observed only after a higher dose of digestate. The increase in soil content of basic macroelements ( $\mathrm{P}, \mathrm{K}, \mathrm{Mg}$ ), also observed in other studies [30,70], can be attributed to their high content in the waste material used. The range of changes is determined by the elemental content of the digestate and the dose applied. The composition of the digestate depends on the substrates used for biogas production and the fermentation process $[3,78,79]$. It contains the biomass of methane fermentation microorganisms and non-fermented organic compounds and minerals. These components are present in quantities comparable to their content in substrates used in biogas. It is worth noting that the application of digestate to soil reduced the amount of available manganese, which is probably related to the improvement of soil sorption properties. One of the factors limiting the use of organic waste in soil fertilisation is the risk of introducing pollutants, including heavy metals. 
The content of trace elements mainly depends on the substrates used in the biogas plant. The digestate used in our research came from a biogas plant with maize silage as the primary substrate. Furthermore, the area where the biogas plant operates and maize is grown is not industrialized. Hence, as shown in Table 2, the content of trace elements in the digestate was very low, well below the permissible level in organic waste adopted in various EU countries [29]. The application of such digestate does not pose a risk of soil contamination. However, for anaerobic co-digestion with cattle and pig slurries, anaerobic digestates may pose a long-term threat to soil health through the accumulation of heavy metals [49].

\section{Conclusions}

The results obtained showed that three-year application of the digestate improved soil properties. It reduced its acidification, improved its sorption properties and increased its organic matter content and macroelement abundance.

The improvement of soil properties and the introduction of easily assimilable nutrients with digestate significantly increased the yield of switchgrass biomass and generally had a positive effect on its quality.

The effect of biogas digestate on switchgrass yield was comparable or higher than mineral fertilisation. Therefore, it can be concluded that the use of digestate in fertilising soils, especially in soils with low fertility, allows the production of large amounts of biomass while limiting the use of mineral fertilisers. It is also a way to manage the digestate produced during biogas production and at the same time, probably a cheaper way to fertilise plants.

Author Contributions: Conceptualization A.G.; Methodology A.G. B.S.; Investigation A.G., R.K.; Formal analysis A.G.; Writing-original draft preparation. A.G., B.S., R.K. All authors have read and agreed to the published version of the manuscript.

Funding: This research was supported by the Ministry of Science and Higher Education of Poland as the part of statutory activities of Faculty of Agrobioengineering and the Institute of Animal Nutrition and Bromathology, University of Life Sciences in Lublin.

Conflicts of Interest: The authors declare no conflict of interest.

\section{References}

1. Raport, E.E.A. Climate change, impacts and vulnerability in Europe 2012. Eur. Environ. 2012, 12. [CrossRef]

2. Wullschleger, S.D.; Davis, E.B.; Borsul, M.E.; Gunderson, C.A.; Lynd, L.R. Biomass production in switchgrass across the United States: Database description and determinants of yield. Agron. J. 2010, 102, 1158-1168. [CrossRef]

3. Brodowska, M.S.; Muszyński, P.; Haliniarz, M.; Brodowski, R.; Kowalczyk-Juśko, A.; Sekutowski, T.; Kurzyna-Szklarek, M. Agronomic aspects of switchgrass cultivation and use for energy purposes. Appl. Ecol. Environ. Res. 2018, 16, 5715-5743. [CrossRef]

4. Vogel, K.P. Switchgrass. In Warm-Season (C4) Grasses; Moser, L.E., Sollenberger, L., Burson, B., Eds.; ASA-CSSA-SSSA: Madison, WI, USA, 2004; pp. 561-588.

5. Fike, J.H.; Parrish, D.J.; Wolf, D.D.; Balasko, J.A.; Green, J.T., Jr.; Rasnake, M.; Reynolds, J.H. Switchgrass production for the upper southeastern USA: Influence of cultivar and cutting frequency on biomass yields. Biomass Bioenergy 2006, 30, 207-213. [CrossRef]

6. Jiang, Q.; Webb, S.L.; Yesudas, C.R.; Bhandari, H.S.; Narasimhamoorthy, B.; Bouton, J.H.; Saha, M.C. Variance components and heritability of biomass yield in switchgrass (Panicum virgatum L.) grown in the Southern Great Plains. Field Crops Res. 2014, 168, 148-155. [CrossRef]

7. Piłat, J.; Majtkowski, W.; Majtkowska, G.; Żurek, G.; Mikołajczak, J. The feeding value assessment of forage from some C-4 grass species in different phases of vegetation. Part III. Panicum virgatum L. Plant Breed. Seed Sci. 2007, 55, 65-73.

8. Muir, J.P.; Sanderson, M.A.; Ocumpaugh, W.R.; Jones, R.M.; Reed, R.L. Biomass Production of 'Alamo' Switchgrass in Response to Nitrogen, Phosphorus, and Row Spacing. Agron. J. 2001, 93, 896-901. [CrossRef]

9. Brejda, J.J.; Brown, J.R.; Wyman, G.W.; Schumacher, W.K. Management of switchgrass for forage and seed production. J. Range Manag. 1994, 47, 22-27. [CrossRef] 
10. An, Y.; Gao, Y.; Ma, Y. Growth performance and weed control effect in response to nitrogen supply for switchgrass after establishment in the semiarid environment. Field Crops Res. 2018, 221, 175-181. [CrossRef]

11. Lai, L.; Kumar, S.; Osborne, S.; Owens, V.N. Switchgrass impact on selected soil parameters, including soil organic carbon, within six years of establishment. Catena 2018, 163, 288-296. [CrossRef]

12. Sanderson, M.A.; Reed, R.L.; McLaughlin, S.B.; Wullschleger, S.D.; Conger, B.V.; Parrish, D.J.; Wolf, D.D.; Taliaferro, C.; Hopkins, A.A.; Ocumpaugh, W.R.; et al. Switchgrass as a sustainable bioenergy crop. Bioresour. Technol. 1996, 56, 83-93. [CrossRef]

13. Keshwani, D.R.; Cheng, J.J. Switchgrass for bioethanol and other value-added applications: A review. Bioresour. Technol. 2009, 100, 1515-1523. [CrossRef] [PubMed]

14. Lemus, R.; Brummer, E.C.; Moore, K.J.; Molstad, N.E.; Burras, C.L.; Barker, M.F. Biomass yield and quality of 20 switchgrass populations in southern Iowa, USA. Biomass Bioenergy 2002, 23, 433-442. [CrossRef]

15. Somerville, C.; Youngs, H.; Taylor, C.; Davis, S.C.; Long, S.P. Feedstocks for lignocellulosic biofuels. Science 2010, 329, 790-792. [CrossRef]

16. Vogel, K.P.; Brejda, J.J.; Walters, D.T.; Buxton, D.R. Switchgrass biomass production in the Midwest USA: Harvest and nitrogen management. Agron. J. 2002, 94, 413-420. [CrossRef]

17. Vogel, K.P.; Gautam, S.; Saathoff, A.J.; Mitchell, R.B. Agronomy \& Horticulture-Faculty Publications. 2011. Available online: http://digitalcommons.unl.edu/agronomyfacpub/1028 (accessed on 21 December 2019).

18. Vogel, K.P.; Sarath, G.; Saathoff, A.J.; Mitchell, R.B. Switchgrass. In Energy Crops; Halford, N.G., Karp, A., Eds.; RSC Energy and Environment Series; Royal Society of Chemistry: London, UK, 2011; Volume 3, pp. 341-380.

19. Ashworth, A.J.; Weiss, S.A.; Keyser, P.D.; Allen, F.L.; Tyler, D.D.; Taylor, A.; Beamer, K.P.; West, C.P.; Pote, D.H. Switchgrass composition and yield response to alternative soil amendments under intensified heat and drought conditions. Agric. Ecosyst. Environ. 2016, 233, 415-424. [CrossRef]

20. Ma, Y.; An, Y.; Shui, J.; Sun, Z. Adaptability evaluation of switchgrass (Panicum virgatum L.) cultivars on the Loess Plateau of China. Plant Sci. 2011, 181, 638-643. [CrossRef]

21. Haquea, M.; Epplin, F.M.; Taliaferro, C.M. Nitrogen and Harvest Frequency Effect on Yield and Cost for Four Perennial Grasses. Agron. J. 2009, 101, 1463-1469. [CrossRef]

22. Miesel, J.R.; Jach-Smith, L.C.; Renz, M.J.; Jackson, R.D. Distribution of switchgrass (Panicum virgatum L.) aboveground biomass in response to nitrogen addition and across harvest dates. Biomass Bioenergy 2017, 100, 74-83. [CrossRef]

23. Stroup, J.A.; Sanderson, M.A.; Muir, J.P.; McFarland, M.J.; Reed, R.L. Comparison of growth and performance in upland and lowland switchgrass types to water and nitrogen stress. Bioresour. Technol. 2003, 86, 65-72. [CrossRef]

24. Guretzky, J.A.; Ball, J.; Cook, B.J. Nitrogen fertiliser rate and weather dictate nutritive value of fall stockpiled bermudagrass. Forage Grassl. 2008, 6. [CrossRef]

25. Jung, G.A.; Shaffer, J.A.; Stout, W.L. Switchgrass and Big Bluestem Responses to Amendments on Strongly Acid Soil. Agron. J. 1988, 80, 669-676. [CrossRef]

26. Staley, T.E.; Stout, W.L.; Jung, G.A. Nitrogen Use by Tall Fescue and Switchgrass on Acidic Soils of Varying Water Holding Capacity. Agron. J. 1991, 83, 732-738. [CrossRef]

27. Yan, Y.; Zhang, L.; Feng, L.; Sun, D.; Dang, Y. Comparison of varying operating parameters on heavy metals ecological risk during anaerobic co-digestion of chicken manure and corn stover. Bioresour. Technol. 2008, 247, 660-668. [CrossRef] [PubMed]

28. Gissen, C.; Prade, T.; Kreuger, E.; Nges, I.A.; Rosenqvist, H.; Svensson, S.E.; Lantz, M.; Mattsson, J.E.; Borjesson, P.; Bjornsson, L. Comparing energy crops for biogas production-yields, energy input and costs in cultivation using digestate and mineral fertilisation. Biomass Bioenergy 2014, 64, 199-210. [CrossRef]

29. WRAP. DC-Agri, Field Experiments for Quality Digestate and Compost in Agriculture-WP1 Report, Prepared by Bhogal et al. 2015. Available online: www.wrapni.org.uk (accessed on 29 January 2020).

30. Różyło, K.; Oleszczuk, P.; Jośko, I.; Kraska, P.; Kwiecińska-Poppe, E.; Andruszczak, S. An ecotoxicological evaluation of soil fertilised with biogas residues or mining waste. Environ. Sci. Pollut. Res. 2015, 22, 7833-7842. [CrossRef]

31. Stefaniuk, M.; Bartminski, P.; Różyło, K.; Dębicki, R.; Oleszczuk, P. Ecotoxicological assessment of residues from different biogas production plants used as fertiliser for soil. J. Hazard. Mater. 2015, 298, 195-202. [CrossRef] 
32. Pivato, A.; Vanin, S.; Raga, R.; Lavagnolo, M.C.; Barausse, A.; Rieple, A.; Laurent, A.; Cossu, R. Use of digestate from a decentralized on-farm biogas plant as fertiliser in soils: An ecotoxicological study for future indicators in risk and life cycle assessment. Waste Manag. 2016, 49, 78-89. [CrossRef]

33. Risberg, K.; Cederlund, H.; Pell, M.; Arthurson, V.; Schnürer, A. Comparative characterization of digestate versus pig slurry and cow manure-Chemical composition and effects on soil microbial activity. Waste Manag. 2017, 61, 529-538. [CrossRef]

34. Pranagal, J.; Tomaszewska-Krojańska, D.; Small, H.; Ligęza, S. Impact of selected waste applications on soil compaction. Agron. Sci. 2019, 74, 19-32. [CrossRef]

35. Galvez, A.; Sinicco, T.; Cayuela, M.L.; Mingorance, M.D.; Fornasier, F.; Mondini, C. Short term effects of bioenergy by-products on soil $\mathrm{C}$ and $\mathrm{N}$ dynamics, nutrient availability and biochemical properties. Agric. Ecosys. Environ. 2012, 160, 3-14. [CrossRef]

36. Smith, J.; Abegaz, A.; Matthews, R.B.; Subedi, M.; Orskov, E.R.; Tumwesige, V.; Smith, P. What is the potential for biogas digesters to improve soil carbon sequestration in Sub-Saharan Africa? Comparison with other uses of organic residues. Biomass Bioenergy 2014, 70, 73-86. [CrossRef]

37. Marcato, C.E.; Mohtar, R.; Revel, J.C.; Pouech, P.; Hafidi, M.; Guiresse, M. Impact of anaerobic digestion on organic matter quality in pig slurry. Int. Biodeterior. Biodegrad. 2009, 63, 260-266. [CrossRef]

38. Garg, R.N.; Pathak, H.; Das, D.K.; Tomar, R.K. Use of fly ash and biogas slurry for improving wheat yield and physical properties of the soil. Environ. Monit. Assess. 2005, 107, 1-9. [CrossRef] [PubMed]

39. Odlare, M.; Pell, M.; Svensson, K. Changes in soil chemical and microbiological properties during 4 years of application of various organic residues. Waste Manag. 2008, 28, 1246-1253. [CrossRef] [PubMed]

40. Insam, H.; Gomez-Brandon, M.; Ascher, J. Manure-based biogas fermentation residues e Friend or foe of soil fertility? Soil Biol. Biochem. 2015, 84, 1-14. [CrossRef]

41. Różyło, K.; Świeca, M.; Gawlik-Dziki, U.; Andruszczak, S.; Kwiecińska-Poppe, P.; Kraska, P. Phytochemical properties and heavy metal accumulation in wheat grain after three years' fertilisation with biogas digestate and mineral waste. Agric. Food Sci. 2017, 26, 148-159. [CrossRef]

42. Makadi, M.; Tomocsik, A.; Eichler-Loebermann, B.; Schiemenz, K. Nutrient cycling by using residues of bioenergy production-Effects of biogas-digestate on plant and soil parameters. Cereal Res. Commun. 2008, 36, 1807-1810. [CrossRef]

43. Andruschkewitsch, M.; Wachendorf, C.; Wachendorf, M. Effects of digestates from different biogas production systems on above and belowground grass growth and the nitrogen status of the plant-soil-system. Grassl. Sci. 2013, 59, 183-195. [CrossRef]

44. Seleiman, M.F.; Selim, S.; Jaakkola, S.; Makela, P.S.A. Chemical composition and in vitro digestibility of whole-crop maize fertilised with synthetic fertiliser or digestate and harvested at two maturity stages in Boreal growing conditions. Agric. Food Sci. 2017, 26, 47-55. [CrossRef]

45. Abubaker, J.; Risberg, K.; Pell, M. Biogas residues as fertilisers - Effects on wheat growth and soil microbial activities. Appl. Energy 2012, 99, 126-134. [CrossRef]

46. Walsh, J.J.; Jones, D.L.; Chadwick, D.R.; Williams, A.P. Repeated application of anaerobic digestate, undigested cattle slurry and inorganic fertiliser N: Impacts on pasture yield and quality. Grass Forage Sci. 2018, 73, 758-763. [CrossRef]

47. Tilvikienè, V.; Šlepetienè, A.; Kadžiulienè, Ž. Effects of 5 years of digestate application on biomass production and quality of cocksfoot (Dactylis glomerata L.). Grass Forage Sci. 2017, 73, 206-217. [CrossRef]

48. Rancane, S.; Karklins, A.; Lazdina, D.; Berzins, P.; Bardule, A.; Butlers, A.; Lazdins, A. The evaluation of biomass yield and quality of Phalaris arundinacea and Festulolium fertilised with bio-energy waste products. Agron. Res. 2016, 14, 198-210.

49. Nkoa, R. Agricultural benefits and environmental risks of soil fertilisation with anaerobic digestates: A review. Agron. Sustain. Dev. 2013, 34, 473-492. [CrossRef]

50. Czekała, W.; Lewicki, A.; Pochwatka, P.; Czekała, A.; Wojcieszak, D.; Jóźwiakowski, K.; Waliszewska, H. Digestate management in polish farms as an element of the nutrient cycle. J. Clean. Prod. 2020, 242, 118454. [CrossRef]

51. IUSS Working Group WRB. World Reference Base for Soil Resources 2014, Update 2015 International Soil Classification System for Naming Soils and Creating Legends for Soil Maps; World Soil Resources Reports No. 106; FAO: Rome, Italy, 2015. 
52. Act on Fertilisers and Fertilisation. Available online: http://isap.sejm.gov.pl/isap.nsf/download.xsp/ WDU20180001259/O/D20181259.pdf (accessed on 29 December 2019).

53. Skowera, B.; Jedrszczyk, E.; Kopcińska, J.; Ambroszczyk, A.M.; Kołtun, A. The effects of hydrothermal conditions during vegetation period on fruit quality of processing tomatoes. Poll. J. Environ. Stud. 2014, 23, 195-202.

54. Association of Official Analytical Chemists (AOAC). Official Methods of Analysis, 18th ed.; Association of Official Analytical Chemists: Arlington, VA, USA, 2005; ISBN 0-935584-77-3.

55. Van Soest, P.J.; Robertson, J.B.; Lewis, B.A. Methods for dietary fibre, neutral detergent fibre and non-starch polysaccharides in relation to animal nutrition. J. Dairy Sci. 1991, 74, 3583-3597. [CrossRef]

56. StatSoft. Electronic Statistic Texbook 2006, Krakow. Available online: http://www.statsoft.pl/textbook/ stathome.html (accessed on 10 December 2019).

57. Koshi, P.T.; Stubbendieck, J.; Eck, H.V.; Mccully, W.G. Switchgrasses: Forage Yield, Forage Quality and Water-use Efficiency. J. Range Manag. 1982, 35, 623-627. Available online: https://pdfs.semanticscholar.org (accessed on 30 January 2020). [CrossRef]

58. Guretzky, J.A.; Biermacher, J.T.; Cook, B.J.; Kering, M.K.; Mosali, J. Switchgrass for forage and bioenergy: Harvest and nitrogen rate effects on biomass yields and nutrient composition. Plant Soil 2011, 339, 69-81. [CrossRef]

59. Rehm, G.W. Yield and quality of a warm-season grass mixture treated with N, P, and atrazine. Agron. J. 1984, 76, 731-734. [CrossRef]

60. Mohammed, T.A.; Raun, W.; Kakani, G.; Zhang, H.; Taylor, R.; Desta, K.G.; Jared, C.; Mullock, J.; Bushong, J.; Sutradhar, A.; et al. Nutrient sources and harvesting frequency on quality biomass production of switchgrass (Panicum virgatum L.) for biofuel. Biomass Bioenergy 2015, 81, 242-248. [CrossRef]

61. Crolla, A.; Kinsley, C.; Pattey, E. Land Application of Digestate; Woodhead Publishing Limited: Philadelphia, PA, USA, 2013; pp. 302-325.

62. George, J.R.; Obermann, D. Spring defoliation to improve summer supply and quality of switchgrass. Agron. J. 1989, 81, 47-52. [CrossRef]

63. Cherney, J.H.; Cherney, D.J.R.; Fox, D.G.; Chase, L.E.; Van Soest, P.J. Evaluating forages for dairy cattle. In Proceedings of the American Forage and Grassland Council, Lancaster, PA, USA, 6-10 March 1994; p. 207.

64. Richner, J.M.; Kallenbach, R.L.; Roberts, C.A. Dual Use Switchgrass: Managing Switchgrass for Biomass Production and Summer Forage. Agron. J. 2014, 106, 1438-1444. [CrossRef]

65. Kering, M.K.; Guretzky, J.A.; Interrante, S.M.; Butler, T.J.; Biermacher, J.T.; Mosali, J. Harvest Timing Affects Switchgrass Production, Forage Nutritive Value, and Nutrient Removal. Crop Sci. 2013, 53, 1809-1817. [CrossRef]

66. Waramit, N.; Moore, K.J.; Fales, S.L. Forage quality of native warm season grasses in response to nitrogen fertilisation and harvest date. Anim. Feed Sci. Technol. 2012, 174, 46-59. [CrossRef]

67. Giannoulis, K.; Bartzialis, D.; Skoufogianni, E.; Danalatos, N. Nutrients Use Efficiency and Uptake Characteristics of Panicum virgatum for Fodder Production. J. Agric. Sci. 2017, 9, 233-234. [CrossRef]

68. National Research Council. Nutrient Requirements of Beef Cattle: Seventh Revised Edition: Update 2000; The National Academies Press: Washington, DC, USA, 2000. [CrossRef]

69. Marschner, P. Mineral Nutrition of Higher Plants, 3rd ed.; Academic Press: London, UK, 2011; pp. $135-178$.

70. Piątek, M.; Bartkowiak, A. Assessment of selected physicochemical properties of soil fertilised with digestate. Water-Environ.-Rural Areas 2019, 19, 55-66.

71. Skowrońska, M.; Filipek, T. Life cycle assessment of fertilisers: A review. Int. Agrophys. 2013, 28, 101-110. [CrossRef]

72. Khalil, M.I.; Hossain, M.B.; Schmidhalter, U. Carbon and nitrogen mineralization in different upland soils of the subtropics treated with organic materials. Soil Biol. Biochem. 2005, 37, 1507-1518. [CrossRef]

73. Bengtsson, G.; Bengtson, P.; Mansson, K.F. Gross nitrogen mineralization-, immobilization-, and nitrification rates as a function of soil C/N ratio and microbial activity. Soil Biol. Biochem. 2013, 35, 143-154. [CrossRef]

74. Brodowski, S.; Amelung, W.; Haumaier, L.; Abetz, Z.; Zech, W. Morphological and chemical properties of black carbon in physical soil fractions as revealed by scanning electron microscopy and energy dispersive x-ray spectroscopy. Geoderma 2005, 128, 116. [CrossRef]

75. Cheng, C.H.; Lehmann, J.; Thies, J.E.; Burton, S.D.; Engelhard, M.H. Oxidation of black carbon by biotic and abiotic processes. Org. Geochem. 2006, 37, 477. [CrossRef] 
76. Łabętowicz, J.M.; Kuszelewski, L.; Korc, M.; Szulc, W. The importance of organic fertilisation for crop stability and ionic balance of light soil. Zesz. Prob. Post. Nauk Rol. 1999, 465, 123-1334.

77. Sanik, J., Jr.; Perhins, A.T.; Schrenk, W.G. The effect of the calcium -magnesium ratio on the solubility and availability of plant nutrients. Soil Sci. Soc. Am. Proc. 1952, 16, 263-267. [CrossRef]

78. Möller, K.; Müller, T. Effects of anaerobic digestion on digestate nutrient availability and crop growth: A review. Eng. Life Sci. 2012, 12, 242-257. [CrossRef]

79. Zirkler, D.; Peters, A.; Kaupenjohann, M. Elemental composition of biogas residues: Variability and alteration during anaerobic digestion. Biomass Bioenergy 2014, 67, 89-98. [CrossRef] 